Prepared in cooperation with the U.S. Army Corps of Engineers

Geologic Framework, Structure, and Hydrogeologic Characteristics of the Knippa Gap Area in Eastern Uvalde and Western Medina Counties, Texas

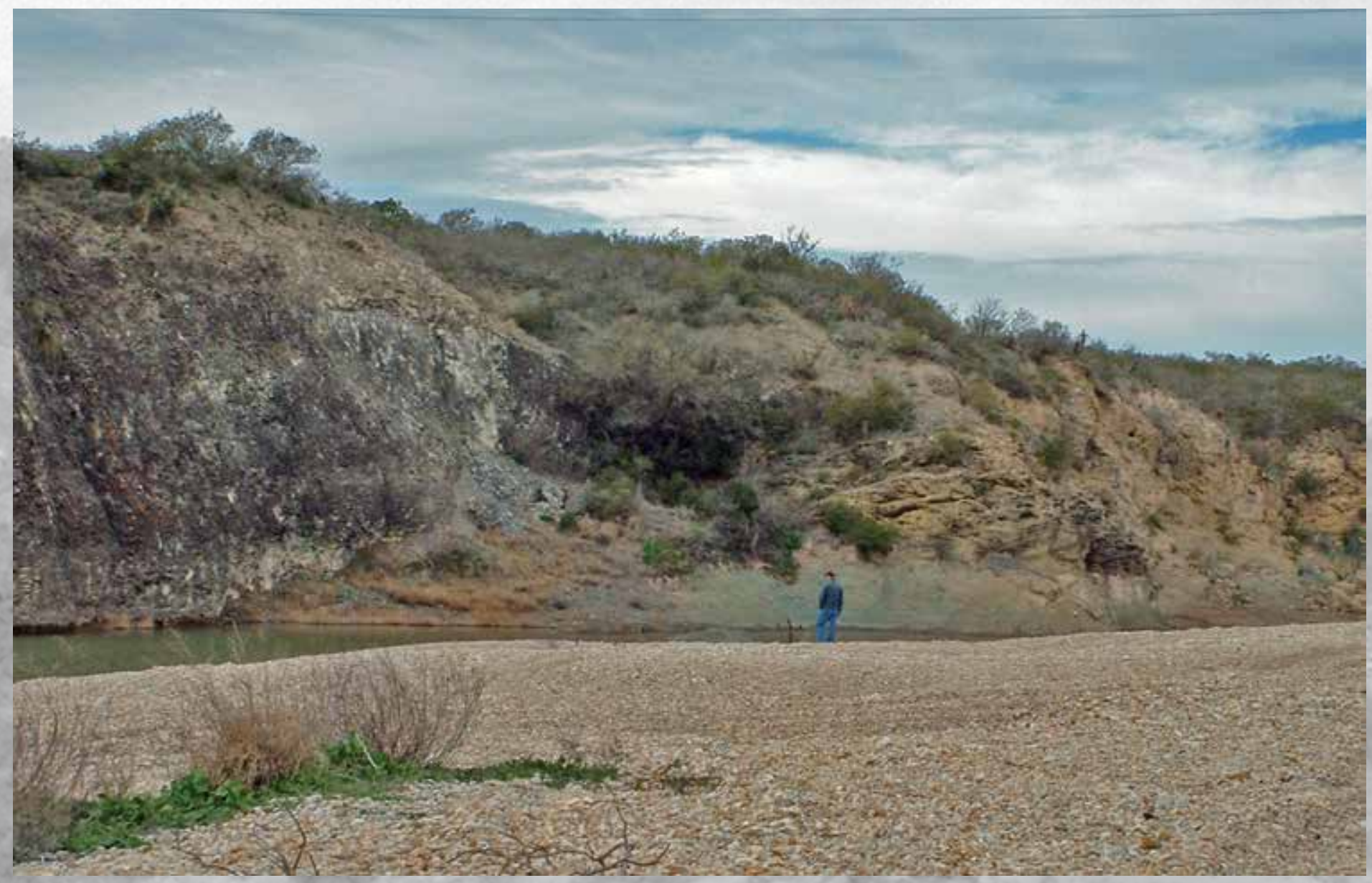

Scientific Investigations Report 2013-5149 
Front cover, Photograph showing outcrop of eroded and dissected extinct volcano located adjacent to the Frio River and east of the city of Uvalde in Uvalde County, Texas. Basalt is remnant of volcanic neck, and adjacent to the basalt is pyroclastic material ranging from fine-grained material to volcanic bombs, which formed the slope of the volcano. Photograph taken January 12, 2012, by Robert R. Morris.

\section{Back cover:}

Top, Photograph showing sandstone ledges in the Escondido Formation located approximately 7 miles south-southeast of the community of D'Hanis in Medina County, Texas. Photograph taken April 13, 2012, by Robert R. Morris.

Bottom, Photograph showing cave in fractured Austin Group rock located approximately 9.3 miles northeast of city of Uvalde in Uvalde County, Texas. Photograph taken August 7, 2012, by Robert R. Morris. 


\section{Geologic Framework, Structure, and Hydrogeologic Characteristics of the Knippa Gap Area in Eastern Uvalde and Western Medina Counties, Texas}

By Allan K. Clark, Diana E. Pedraza, and Robert R. Morris

Prepared in cooperation with the U.S. Army Corps of Engineers

Scientific Investigations Report 2013-5149 


\section{U.S. Department of the Interior \\ SALLY JEWELL, Secretary}

\section{U.S. Geological Survey \\ Suzette M. Kimball, Acting Director}

\section{U.S. Geological Survey, Reston, Virginia: 2013}

For more information on the USGS — the Federal source for science about the Earth, its natural and living resources, natural hazards, and the environment, visit http://www.usgs.gov or call 1-888-ASK-USGS.

For an overview of USGS information products, including maps, imagery, and publications, visit http://www.usgs.gov/pubprod

To order this and other USGS information products, visit http://store.usgs.gov

Any use of trade, firm, or product names is for descriptive purposes only and does not imply endorsement by the U.S. Government.

Although this information product, for the most part, is in the public domain, it also may contain copyrighted materials as noted in the text. Permission to reproduce copyrighted items must be secured from the copyright owner.

Suggested citation:

Clark, A.K., Pedraza, D.E., and Morris, R.R., 2013, Geologic framework, structure, and hydrogeologic characteristics of the Knippa Gap area in eastern Uvalde and western Medina Counties, Texas: U.S. Geological Survey Scientific Investigations Report 2013-5149, 35 p., 1 pl., http://pubs.usgs.gov/sir/2013/5149/. 


\section{Acknowledgments}

This study was completed on private ranchland, and the authors would like to extend their thanks to John Hoyt and others from the Edwards Aquifer Authority (EAA) for facilitating access to the study area. In addition, grateful appreciation is extended to the land owners for granting access to their land, which made completion of this investigation possible. 



\section{Contents}

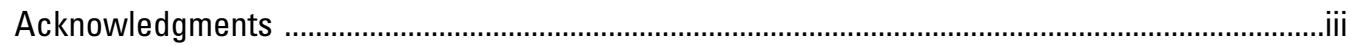

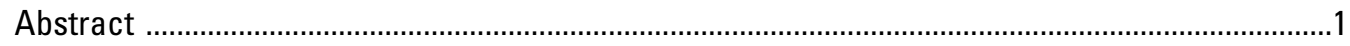

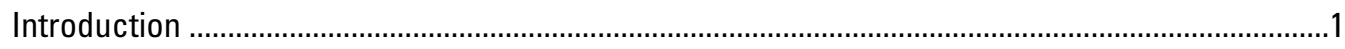

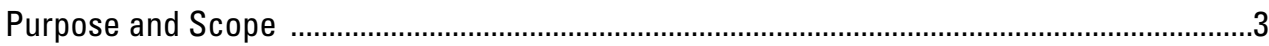

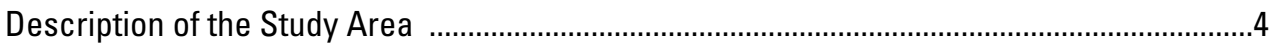

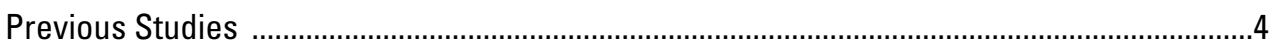

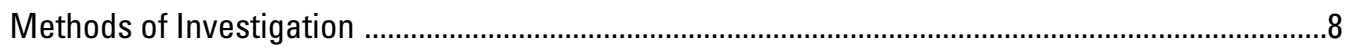

Geologic Interpretation Methods ....................................................................................

Geodatabase Development and Data Management ...........................................................10

Geologic Framework, Structure, and Hydrogeologic Characteristics ...........................................11

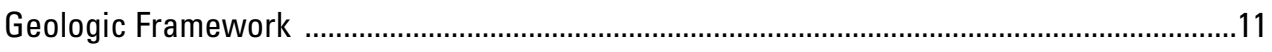

Lower Cretaceous Series ..............................................................................................

Upper Cretaceous Series ...............................................................................................12

Upper Cretaceous Series Igneous Rocks ........................................................................15

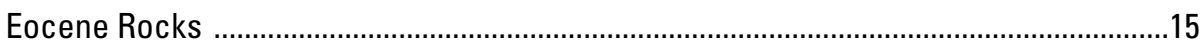

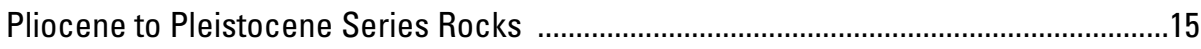

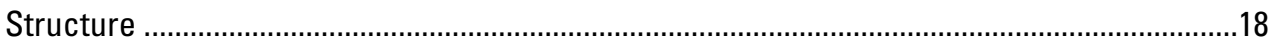

Hydrogeologic Cross-Section A-A' ......................................................................19

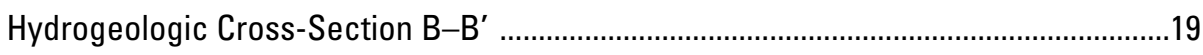

Hydrogeologic Characteristics ...................................................................................... 19

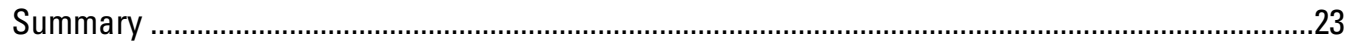

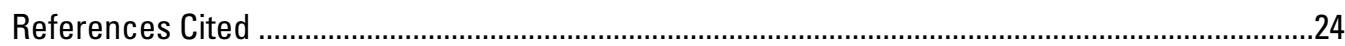

Appendix 1. Wells Included in a Geodatabase of Geologic Framework, Structure, and Hydrogeologic Characteristics of the Knippa Gap Area in Eastern Uvalde and Western Medina Counties, Texas ......................................................................29

\section{Plate}

[In pocket]

Plate 1. Geologic framework, structure, and hydrogeologic characteristics of the Knippa Gap area in eastern Uvalde and western Medina Counties, Texas

\section{Figures}

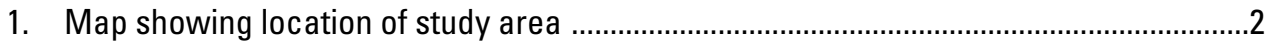

2. Map showing regional depositional provinces, boundary of the Balcones Fault Zone, and the Balcones escarpment .................................................................................

3. Map showing physiographic provinces of Texas ...............................................................5 
4. Diagram showing summary of the lithologic and hydrogeologic characteristics of the stratigraphic units of the Devils River Trend in eastern Uvalde and western Medina Counties, Texas

5. Diagram showing summary of the lithologic and hydrogeologic characteristics of the stratigraphic units of the Maverick Basin in eastern Uvalde County, Texas ..........7

6. Aerial photograph showing a linear fault identified by the vegetation growing along its surface expression

7. Aerial photograph showing circular bands of vegetation that correlate with isolated exposures of igneous rock in an area composed primarily of alluvium.

8. Photograph showing the abundance of llymatogyra arietina in the Del Rio Clay located in northeastern Uvalde County, Texas

9. Photograph showing contact between Buda Limestone (hillside) and Del Rio Clay (bed of creek) located on the west side of bridge at tributary to Seco Creek in northwestern Medina County, Texas

10. Photograph showing exposed Austin Group in road cut excavation located on south side of U.S. Highway 90 and approximately midway between Sabinal and Knippa Texas, eastern Uvalde County, Tex.

11. Photograph showing Inoceramus sp. fossil that is typical of the Austin Group located in the bed of the Leona River approximately 3 miles south-southeast of city of Uvalde in Uvalde County, Texas

12. Photograph showing sandstone ledges in the Escondido Formation located approximately 7 miles south-southeast of the community of D'Hanis in Medina County, Texas

13. Photograph showing outcrop of eroded and dissected extinct volcano located adjacent to the Frio River and east of the city of Uvalde in Uvalde County, Texas .........16

14. Photograph showing columnar jointing common in igneous rocks located adjacent to the Frio River and east of the city of Uvalde in Uvalde County, Texas

15. Photograph showing caliche-cemented Uvalde Gravel located approximately 5.3 miles southeast of the town of D'Hanis in Medina County, Texas

16. Diagram showing idealized view of the relay-ramp structure that dips to the northeast from the Uvalde Salient in Uvalde County, the relay-ramp structure that dips to the southwest from Medina County, and the inferred direction of groundwater flow paths towards the Knippa Gap structural low (trough)

17. Photograph showing channel porosity developed along a bedding plane in the Austin Group located near the intermittent Leona Springs 2 on the Leona River in Uvalde County, Texas

18. Photograph showing cave in fractured Austin Group rock located approximately 9.3 miles northeast of city of Uvalde in Uvalde County, Texas 


\section{Conversion Factors}

Inch/Pound to SI

\begin{tabular}{|c|c|c|}
\hline Multiply & By & To obtain \\
\hline \multicolumn{3}{|c|}{ Length } \\
\hline foot $(\mathrm{ft})$ & 0.3048 & meter $(\mathrm{m})$ \\
\hline mile (mi) & 1.609 & kilometer $(\mathrm{km})$ \\
\hline
\end{tabular}

Vertical coordinate information is referenced to the North American Vertical Datum of 1988 (NAVD 88).

Horizontal coordinate information is referenced to the North American Datum of 1983 (NAD 83).

Altitude, as used in this report, refers to distance above the vertical datum.

Concentrations of chemical constituents in water given in milligrams per liter (mg/L). 



\title{
Geologic Framework, Structure, and Hydrogeologic Characteristics of the Knippa Gap Area in Eastern Uvalde and Western Medina Counties, Texas
}

\author{
By Allan K. Clark, Diana E. Pedraza, and Robert R. Morris
}

\section{Abstract}

The Edwards aquifer is the primary source of potable water for the San Antonio area in south-central Texas. The Knippa Gap was postulated to channel or restrict flow in the Edwards aquifer in eastern Uvalde County, and its existence was based on a series of numerical simulations of groundwater flow in the aquifer. To better understand the function of the area known as the Knippa Gap as it pertains to its geology and structure, the geologic framework, structure, and hydrogeologic characteristics of the area were evaluated by the U.S. Geological Survey in cooperation with the U.S. Army Corps of Engineers-Fort Worth District.

The principal structural feature in the San Antonio area is the Balcones Fault Zone, which is the result of Miocene age faulting. In Medina County, the faulting of the Balcones Fault Zone has produced a relay-ramp structure that dips to the southwest from the Edwards aquifer recharge zone and extends westward and below land surface from Seco Creek.

Groundwater flow paths in the Edwards aquifer are influenced by faulting and geologic structure. Some faults act as barriers to groundwater flow paths where the aquifer is offset by 50 percent or more and result in flow moving parallel to the fault. The effectiveness of a fault as a barrier to flow changes as the amount of fault displacement changes. The structurally complex area of the Balcones Fault Zone contains relay ramps, which form in extensional fault systems to allow for deformation changes along the fault block. In Medina County, the faulting of the Balcones Fault Zone has produced a relay-ramp structure that dips to the southwest from the Edwards aquifer recharge zone. Groundwater moving down the relay ramp in northern Medina County flows downgradient (downdip) to the structural low (trough) from the northeast to the southwest. In Uvalde County, the beds dip from a structural high known as the Uvalde Salient. This results in groundwater moving from the structural high and downgradient (dip) towards a structural low (trough) to the northeast. These two opposing structural dips result in a subsurface structural low (trough) locally referred to as the Knippa Gap. This trough is located in eastern Uvalde County beneath the towns of Knippa and Sabinal.
By using data that were compiled and collected for this study and previous studies, a revised map was constructed depicting the geologic framework, structure, and hydrogeologic characteristics of the Knippa Gap area in eastern Uvalde and western Medina Counties, Tex. The map also shows the interpreted structural dip directions and interpreted location of a structural low (trough) in the area known as the Knippa Gap.

\section{Introduction}

The Edwards aquifer is the primary source of potable water for the San Antonio area (fig. 1) in south-central Texas (Edwards Aquifer Authority, 2013; Hovorka and others, 1996). San Antonio is currently the seventh largest city in the United States and second largest city in Texas (U.S. Census Bureau, 2012a). The population of south-central Texas is projected to increase by 34 percent between 2010 and 2030 (Texas Water Development Board, 2010). Given this projected growth, the ability to effectively manage sources of potable water is a major concern for local and regional water-resource managers.

Computer simulations of the Edwards aquifer are among the tools local and regional water-resource managers use to manage sources of potable water in south-central Texas. The accuracy of computer simulations (Maclay and Land 1988; Kuniansky and Holligan, 1994; Lindgren and others, 2004; Lindgren, 2006) of the Edwards aquifer can be improved by incorporating more detailed information pertaining to the geology and geologic structure controlling groundwater flow paths of the system. This is particularly true for a part of the Edwards aquifer locally known as the Knippa Gap in the western part of the Edwards aquifer near Knippa, Tex. (fig. 1).

The Knippa Gap was postulated by Maclay and Land (1988) to channel or restrict flow in the Edwards aquifer in eastern Uvalde County (fig. 1), and its existence was based on a series of numerical simulations of groundwater flow in the aquifer. Those numerical simulations were made in an attempt to synthesize the geologic, structural, and hydrogeologic characteristics of the aquifer (Maclay and Land, 1988). The 


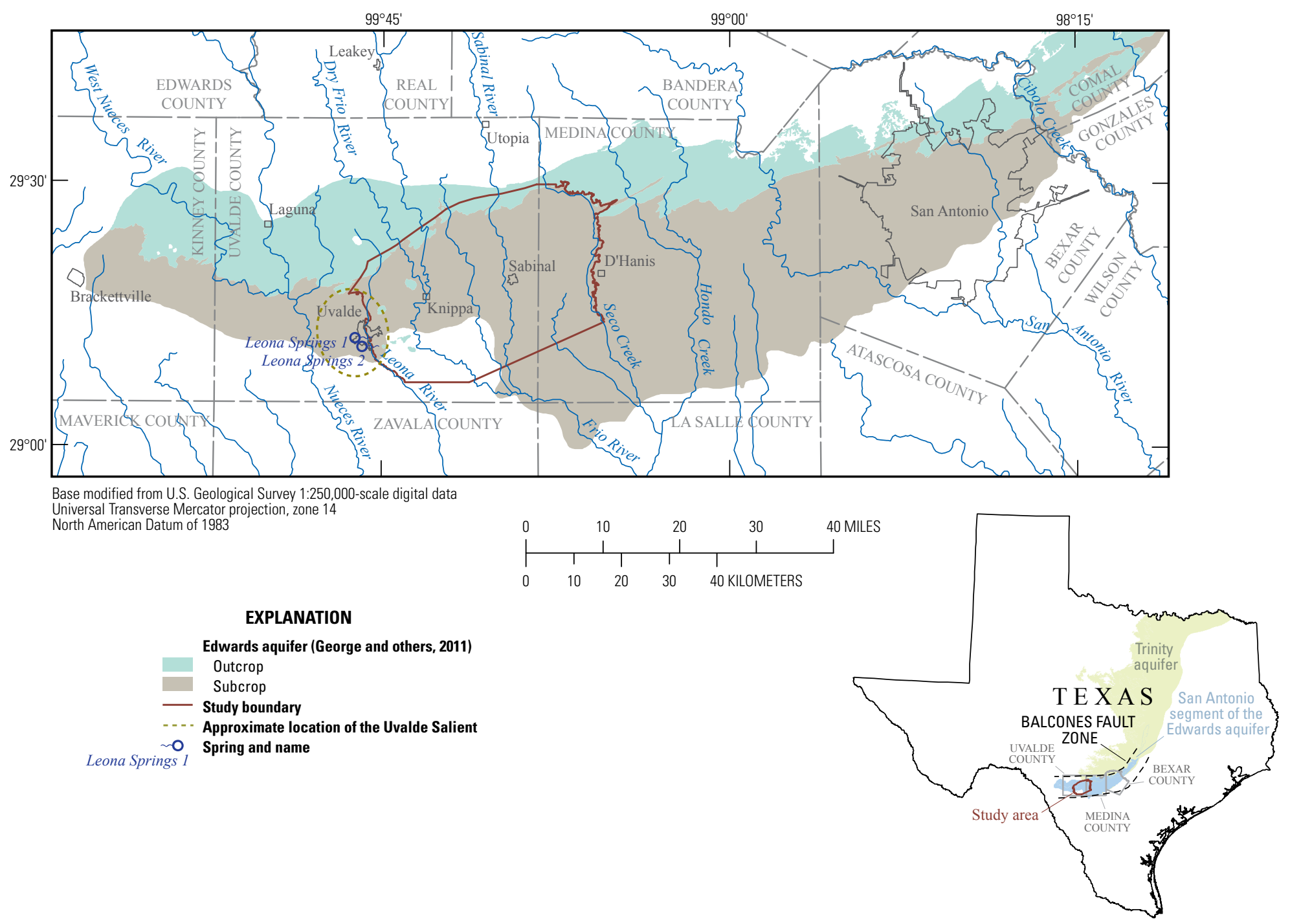

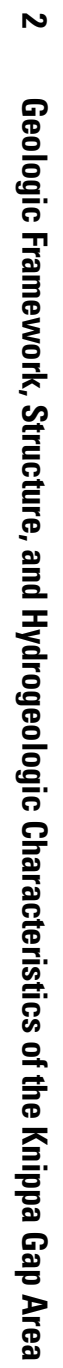

Figure 1. Location of study area. 
Knippa Gap occurs near the boundary of the Devils River Trend and Maverick Basin depositional provinces (fig. 2). Maclay and Land (1988, p. A43) provide a detailed description of the Knippa Gap, referring to it as a "narrow opening within an extensive, complex barrier system." Maclay and Land (1988, p. A43) go on to explain that groundwater flows through the Knippa Gap originating from what they referred to as "the western storage unit" and "the western Medina storage units," historical terms referring to the San Antonio segment of the Edwards aquifer recharge zone (Maclay and Land, 1988). Maclay and Land (1988, p. A43) explain that the groundwater flows "southward and downdip toward the southernmost part of the [Edwards] aquifer in southeastern Uvalde and southwestern Medina Counties," and that the Knippa Gap "occurs in the Devils River [Formation] and lies near the lesspermeable rocks of the Maverick Basin."

To better understand the function of the area known as the Knippa Gap as it pertains to its geology and structure, the geologic framework, structure, and hydrogeologic characteristics of the area were evaluated by the U.S. Geological Survey (USGS) in cooperation with the U.S. Army Corps of Engineers (USACE) - Fort Worth District.

\section{Purpose and Scope}

The purpose of this report is to describe the geologic framework, structure, and hydrogeologic characteristics of

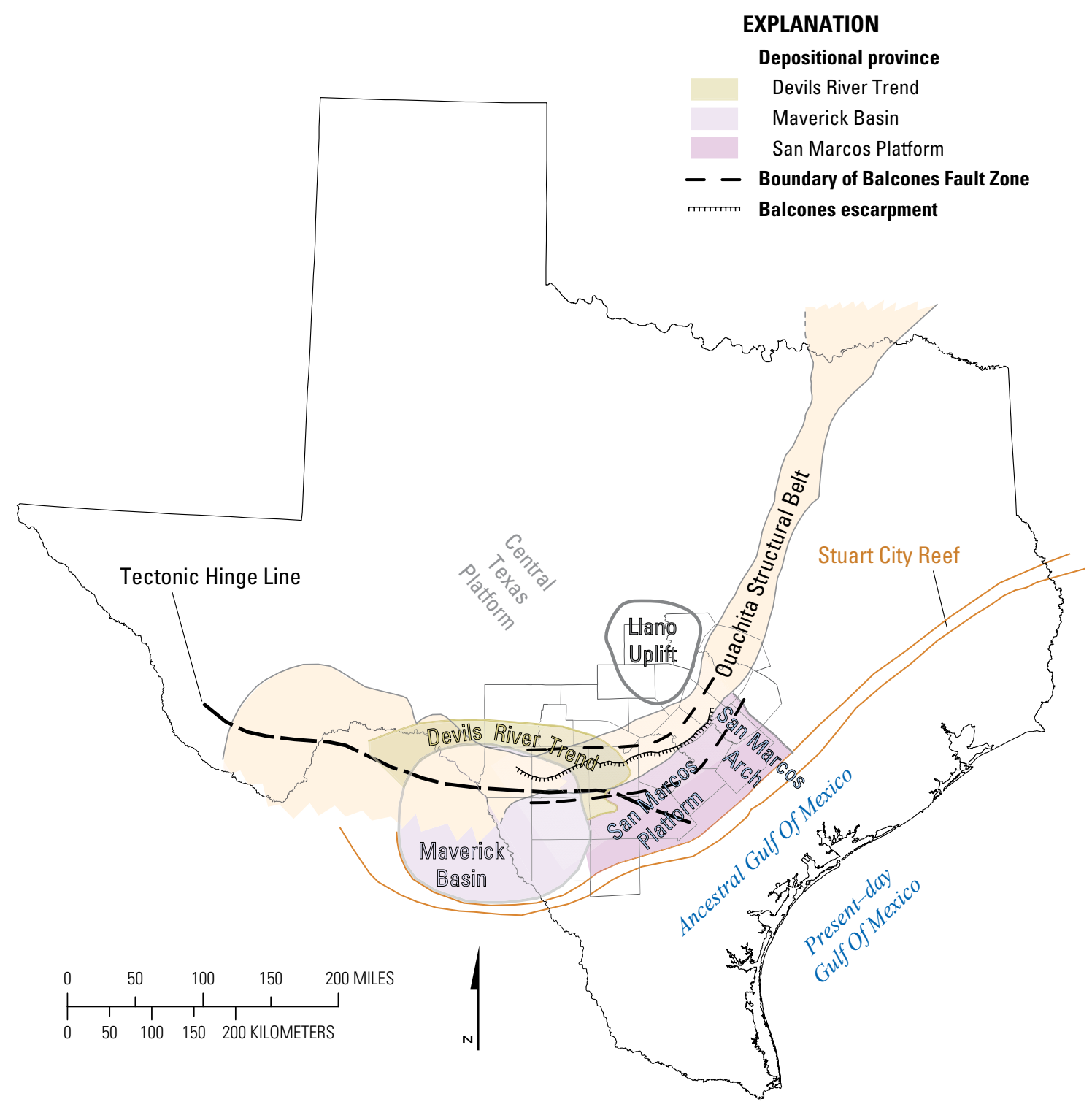

Figure 2. Regional depositional provinces, boundary of the Balcones Fault Zone, and the Balcones escarpment. Figure modified from Abbott and Woodruff, 1986. 
the Knippa Gap area of the Devils River Trend and Maverick Basin (fig. 2) in eastern Uvalde and western Medina Counties, Tex. This report includes a surficial geologic map developed on the basis of previous investigations and information obtained during field mapping. The map includes two hydrogeologic cross sections of the study area. A description of the geodatabase developed to manage project data and spatially relate the data is included in the report.

\section{Description of the Study Area}

The study area (fig. 1) is in eastern Uvalde and western Medina Counties, south-central Texas, and is located at the northern boundary of the Coastal Plain physiographic province (fig. 3) (Fenneman, 1931). The northern boundary of the study area coincides generally with the surficial exposure of the Edwards aquifer (fig. 1) outcrop in the Balcones Fault Zone (fig. 2). The Balcones Fault Zone crosses through the study area in a series of parallel to subparallel, vertical to nearly vertical, en echelon, normal faults that are predominantly downthrown to the south and southeast (Sellards and others, 1932). The Balcones Fault Zone lies on the boundary between the western part of the Coastal Plain section of the Coastal Plain physiographic province and the Edwards Plateau section of the Great Plains physiographic province (fig. 3) (Fenneman and Johnson, 1946).

The most prominent topographic feature of the Balcones Fault Zone is the Balcones escarpment, a topographic escarpment in south-central Texas (Sellards, 1919). Based on data obtained for this study, change in land-surface altitude across the Balcones Fault Zone is approximately 500 feet (ft); ranging from an altitude of approximately $1,150 \mathrm{ft}$ at the inner edge of the western part of the Coastal Plain to an altitude of approximately 1,650 ft near the southern margin of the Edwards Plateau. The land surface in the study area is nearly horizontal to gently sloping with elevated areas separated by broad, level valleys, and each of the valleys are incised by streams (Stevens and Richmond, 1970; Dittmar and others, 1977).

The rocks within the study area are sedimentary and igneous and range in age from the Lower Cretaceous to the Pleistocene. The sedimentary rocks are limestone, chalk, gravel, sand, silt, and clay. The igneous rocks are ultramafic to intermediate in composition. The formations present in the study area from bottom to top are: Glen Rose Limestone, West Nueces Formation, McKnight Formation, Salmon Peak Formation, Devils River Formation, Del Rio Clay, Buda Limestone, Eagle Ford Group, Austin Group, Anacacho Limestone, Escondido Formation, Indio Formation, Uvalde Gravel, and Leona Formation (figs. 4-5). The specific formation present in the study area varies east to west from the Devils River Trend to the Maverick Basin depositional province (figs. 4-5). In the study area, the Edwards aquifer is formed within the Devils River Formation, Salmon Peak Formation, McKnight Formation, and West Nueces Formation.

\section{Previous Studies}

Numerous reports have been published pertaining to the geology and groundwater resources of Uvalde and Medina Counties, Tex. Shumard (1860) named the Austin Formation for outcrops in Travis County, Tex., which subsequently redefined the stratigraphic location by White and Hill (1887). The Escondido Formation was first named and defined by Dumble (1892). Hill and Vaughn (1898) named and described the extent of the Edward Limestone for the Edwards Plateau, Nueces and Uvalde quadrangles, southwestern Texas of which it is the chief component of the scarps and mesas. Hill and Vaughn (1898) also named the Del Rio Clay and described its location for outcrops near Del Rio, Tex., and named and described the Anacacho Formation. Vaughan credited Hill with defining and naming the Buda Limestone for outcrops near Buda, Tex., and Eagle Ford Formation for outcrops near the old community of Eagle Ford, Dallas County, Tex. (Vaughan, 1900b). The Devils River Formation was named by Udden (1907) for the limestone between the Glen Rose Limestone and the Del Rio Clay. Liddle (1918) was the first to discuss the geology and mineral resources of Medina County, Tex. The Indio Formation was designated by Trowbridge (1923) for outcrops on the Indio Ranch, Maverick and Dimmit Counties, Tex. Sayre (1936) separated the Georgetown Formation from the Edwards Limestone, documenting that they were distinct formations composed primarily of limestone. The Austin Chalk was assigned Group status by Wilmarth (1938). Lozo and Smith (1964) substantially revised the stratigraphic nomenclature of the various geologic units associated with the Edwards Limestone, resulting in an improved understanding of the geologic structure. The surface geology in the Knippa area was mapped by Barnes (1974); Barnes also redefined the Eagle Ford Group, separating the Boquillas Formation (not in study area) from the Eagle Ford Group (Barnes, 1977). The transition zone from the Maverick Basin to the Devils River Trend was mapped by Miller (1983) who also mapped the basal nodular member of the Devils River and West Nueces Formations and subdivided the McKnight Formation into lower, middle, and upper members in the north-central part of Uvalde County. Clark and Small (1997) and Clark (2003) investigated the geologic framework and hydrogeologic characteristics of the Edwards aquifer in Uvalde County, Tex.

Although sedimentary rocks are most common in the study area, the existence of igneous rocks has been known for more than 100 years (Vaughan, 1900a). Lonsdale (1927) completed field and laboratory analyses of the igneous rocks outcropping in central Texas and published thicknesses of formations within Uvalde County, Tex. Smith and others (2003) published an aeromagnetic survey of Medina and Uvalde Counties to delineate subsurface igneous bodies. The igneous provenance was delineated and briefly explained by Smith and others (2008). 


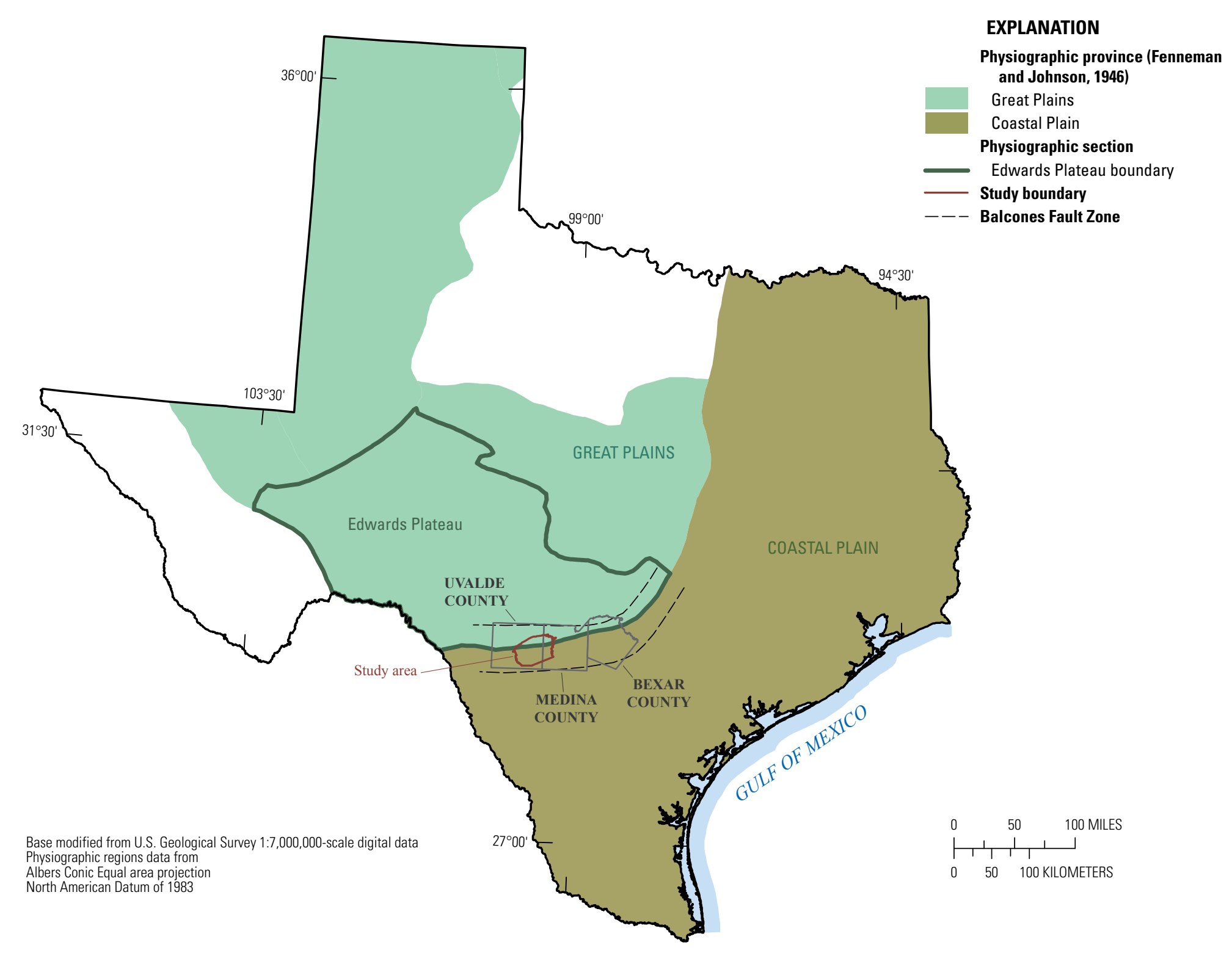

Figure 3. Physiographic provinces of Texas. 
Figure 4. Summary of the lithologic and hydrogeologic characteristics of the stratigraphic units of the Devils River Trend in eastern Uvalde and western Medina Counties, Texas.

[Groups and formations modified from Dumble (1892), Hill and Vaughn (1898), Hill (1901), Udden (1907), Wilmarth (1938), Lozo and Smith (1964), Humphreys (1984), Miller (1983), and Barnes (1977); lithology modified from Dunham (1962); and porosity type modified from Choquette and Pray (1970)]

\begin{tabular}{|c|c|c|c|c|c|c|c|c|c|c|c|}
\hline $\begin{array}{c}\text { Se- } \\
\text { ries }\end{array}$ & & oup/fo & rmation & $\begin{array}{l}\text { Thickness } \\
\text { (feet) }\end{array}$ & & Lithology & $\begin{array}{c}\text { Field } \\
\text { identification }\end{array}$ & $\begin{array}{l}\text { Hydrologic } \\
\text { unit }\end{array}$ & $\begin{array}{l}\text { Hydrologic } \\
\text { function }\end{array}$ & $\begin{array}{c}\text { Cavern } \\
\text { development }\end{array}$ & $\begin{array}{c}\text { Porosity } \\
\text { type }\end{array}$ \\
\hline 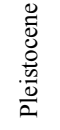 & \multicolumn{3}{|c|}{ Leona Formation } & $0-120$ & \multicolumn{2}{|c|}{ Red-reddish gray silt, fine gravels } & $\begin{array}{l}\text { Unconsolidated gravels in and } \\
\text { adjacent to streambeds }\end{array}$ & Leona aquifer & Aquifer & None & Fabric selective interparticle \\
\hline$\frac{\mathscr{\Xi}}{\stackrel{\Xi}{\Xi}}$ & \multicolumn{3}{|c|}{ Uvalde Gravel } & $0-20$ & \multicolumn{2}{|c|}{$\begin{array}{l}\text { Loose pebbles, cobbles, gravels. } \\
\text { Gravels often cemented with } \\
\text { caliche }\end{array}$} & $\begin{array}{l}\text { Large gravels in areas of higher } \\
\text { relief often cemented with } \\
\text { caliche }\end{array}$ & None & None & None & Fabric selective interparticle \\
\hline \multirow{6}{*}{ 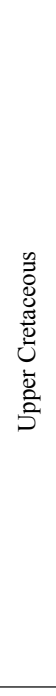 } & 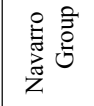 & $\begin{array}{r}\text { Esco } \\
\text { Fo }\end{array}$ & $\begin{array}{l}\text { idido } \\
\text { rmation }\end{array}$ & $200-875$ & $\begin{array}{r}\text { Fine-gr: } \\
\text { inter } \\
\text { pyro }\end{array}$ & $\begin{array}{l}\text { ned sandstone, with } \\
\text { edded shale, clay, and } \\
\text { astic material }\end{array}$ & $\begin{array}{l}\text { Brown, fine-grained sandstone, } \\
\text { locally fossiliferous }\end{array}$ & & Confining unit & None & $\begin{array}{l}\text { Fabric selective interparticle; } \\
\text { nonfabric selective fractures }\end{array}$ \\
\hline & 离言 & $\begin{aligned} & \text { Anac } \\
& \text { L }\end{aligned}$ & $\begin{array}{l}\text { acho } \\
\text { mestone }\end{array}$ & 188 & $\begin{array}{r}\text { Massive } \\
\text { inter }\end{array}$ & $\begin{array}{l}\text { mudstone to packstone, with } \\
\text { edded bentonitic clay }\end{array}$ & $\begin{array}{l}\text { White to gray packstone, } \\
\text { with thick sequences of } \\
\text { bentonitic clays }\end{array}$ & 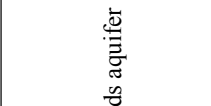 & Confining unit & None & $\begin{array}{l}\text { Fabric selective moldic, nonfabric } \\
\text { selective fractures and bedding } \\
\text { plane }\end{array}$ \\
\hline & \multicolumn{3}{|c|}{ Austin Group } & 246 & \multicolumn{2}{|c|}{$\begin{array}{l}\text { Massive, chalky to marly, fossiliferous } \\
\text { mudstone }\end{array}$} & $\begin{array}{l}\text { White, chalky limestone; } \\
\text { Gryphaea aucella, } \\
\text { Inoceramus sp. }\end{array}$ & 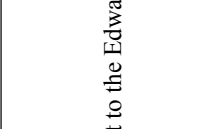 & $\begin{array}{l}\text { Confining unit; aquifer } \\
\text { where connected to } \\
\text { Edwards by faults/ } \\
\text { fractures }\end{array}$ & $\begin{array}{l}\text { Minor along fracture/ } \\
\text { faults }\end{array}$ & $\begin{array}{l}\text { Fabric selective moldic and } \\
\text { interparticle, nonfabric } \\
\text { selective fractures, bedding } \\
\text { plane, channels and caves }\end{array}$ \\
\hline & \multicolumn{3}{|c|}{ Eagle Ford Group } & 71 & \multicolumn{2}{|c|}{$\begin{array}{l}\text { Brown, flaggy, sandy shale and } \\
\text { argillaceous limestone }\end{array}$} & $\begin{array}{l}\text { Thin brown flagstones; } \\
\text { petroliferous, fossil } \\
\text { fragments and fossils of } \\
\text { Inoceramus } \text { sp. }\end{array}$ & $\begin{array}{l}\Xi \\
0 \\
.0 \\
. 尹 \\
0 \\
0 \\
0\end{array}$ & Confining unit & None & $\begin{array}{l}\text { Fabric selective interparticle, } \\
\text { nonfabric selective fractures } \\
\text { and bedding plane }\end{array}$ \\
\hline & \multirow{3}{*}{ 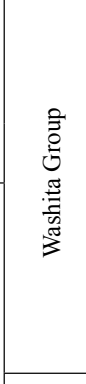 } & \multicolumn{2}{|c|}{ Buda Limestone } & 72 & \multicolumn{2}{|c|}{ Buff to light-gray, dense mudstone } & $\begin{array}{l}\text { Porcelaneous limestone, } \\
\text { nodular, iron nodules, iron } \\
\text { staining, iron replacement } \\
\text { of fossils }\end{array}$ & 芯 & Confining unit & Minor surface karst & Nonfabric selective fractures \\
\hline & & \multicolumn{2}{|c|}{ Del Rio Clay } & 70 & \multicolumn{2}{|c|}{ Blue-green to yellow-brown clay } & \begin{tabular}{|c|}
$\begin{array}{c}\text { Fossiliferous; Ilymatogyra } \\
\text { arietina }\end{array}$ \\
\end{tabular} & & Confining unit & None & Confining unit \\
\hline \multirow{4}{*}{ 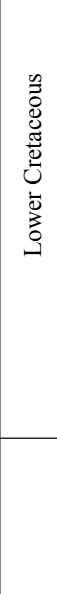 } & & \multirow{3}{*}{ 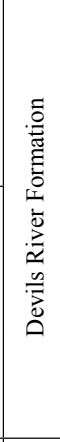 } & Undivided & 270 & Upper & \begin{tabular}{|l|} 
Light-grey wackestone, \\
packstone, miliolid \\
grainstone, rudist \\
boundstone, shell \\
fragments, chert nodules \\
and beds \\
\end{tabular} & \multirow{2}{*}{$\begin{array}{l}\text { Most fossils (caprinids, } \\
\text { monopleurids, and } \\
\text { requieniids) near top. } \\
\text { Highly dissolutioned and } \\
\text { brecciated, with vuggy } \\
\text { porosity and most chert near } \\
\text { middle. Relatively massive } \\
\text { and burrowed, with little } \\
\text { chert near base. }\end{array}$} & \multirow{3}{*}{ 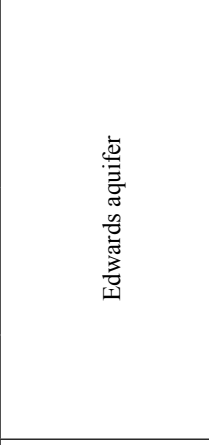 } & Aquifer & $\begin{array}{l}\text { Most extensive near top } \\
\text { with some sinkhole } \\
\text { development near } \\
\text { middle and some } \\
\text { cavern development }\end{array}$ & $\begin{array}{l}\text { Upper part: Fabric selective } \\
\text { moldic; nonfabric selective } \\
\text { bedding plane, fracture, } \\
\text { vug, channel and cave; } \\
\text { Middle part: nonfabric } \\
\text { selective vug; }\end{array}$ \\
\hline & \multirow{2}{*}{ 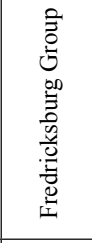 } & & & 260 & Lower & $\begin{array}{l}\text { Miliolid, shell fragmented, } \\
\text { mudstone to grainstone, } \\
\text { chert; mudstone to } \\
\text { grainstone burrowed }\end{array}$ & & & & $\begin{array}{l}\text { associated with } \\
\text { solutionally enlarged } \\
\text { fractures near base }\end{array}$ & $\begin{array}{l}\text { Lower part: nonfabric selective } \\
\text { burrows, intercrystaline, } \\
\text { nonfabric selective vugs, } \\
\text { fractures }\end{array}$ \\
\hline & & & $\begin{array}{l}\text { Basal } \\
\text { nodular }\end{array}$ & $20-70$ & \multicolumn{2}{|c|}{$\begin{array}{l}\text { Nodular, burrowed mudstone to } \\
\text { wackestone miliolids, gastropods, } \\
\text { and Exogyra texana }\end{array}$} & $\begin{array}{l}\text { Nodular gray mudstone, black } \\
\text { rotund bodies }\end{array}$ & & $\begin{array}{l}\text { Confining unit; aquifer } \\
\text { where solutionally } \\
\text { enhanced }\end{array}$ & $\begin{array}{l}\text { Minor, primarily near } \\
\text { contact with Glen } \\
\text { Rose Limestone }\end{array}$ & Nonfabric selective fractures \\
\hline & 存言 & \multicolumn{2}{|c|}{$\begin{array}{l}\text { Glen Rose } \\
\text { Limestone }\end{array}$} & $900-1,530$ & \multicolumn{2}{|c|}{$\begin{array}{l}\text { Tan, alternating layers of medium- } \\
\text { bedded limestone and argillaceous } \\
\text { limestone. }\end{array}$} & $\begin{array}{l}\text { Stairstep topography, tan } \\
\text { mudstones, marly, thin } \\
\text { bedded, Tylostoma } \text { sp., } \\
\text { Turritella sp., Protocardia } \\
\text { texana }\end{array}$ & 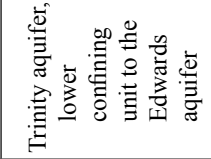 & $\begin{array}{l}\text { Confining unit to } \\
\text { Edwards aquifer; } \\
\text { aquifer where } \\
\text { evaporite beds } \\
\text { present }\end{array}$ & $\begin{array}{l}\text { Minor, related to } \\
\text { fractures, faults, and } \\
\text { bedding plane }\end{array}$ & $\begin{array}{l}\text { Fabric selective boxwork, breccia, } \\
\text { moldic; nonfabric selective } \\
\text { fractures and caves }\end{array}$ \\
\hline
\end{tabular}


Figure 5. Summary of the lithologic and hydrogeologic characteristics of the stratigraphic units of the Maverick Basin in eastern Uvalde County, Texas.

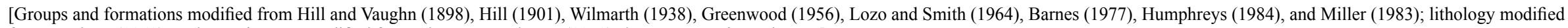
from Dunham (1962); and porosity type modified from Choquette and Pray (1970); *, not present in study area]

\begin{tabular}{|c|c|c|c|c|c|c|c|c|c|c|}
\hline $\begin{array}{l}\text { Se- } \\
\text { ries }\end{array}$ & \multicolumn{3}{|c|}{ Group/formation } & $\begin{array}{c}\text { Thickness } \\
\text { (feet) }\end{array}$ & Lithology & Field identification & $\begin{array}{l}\text { Hydro- } \\
\text { logic unit }\end{array}$ & $\begin{array}{l}\text { Hydrologic } \\
\text { function }\end{array}$ & $\begin{array}{c}\text { Cavern } \\
\text { development }\end{array}$ & $\begin{array}{c}\text { Porosity } \\
\text { type }\end{array}$ \\
\hline 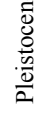 & \multicolumn{3}{|c|}{ Leona Formation } & $0-120$ & Red-reddish gray silt, fine gravels & $\begin{array}{l}\text { Unconsolidated gravels in and adjacent to } \\
\text { streambeds }\end{array}$ & $\begin{array}{l}\text { Leona } \\
\quad \text { aquifer }\end{array}$ & Aquifer & None & Fabric selective interparticle \\
\hline 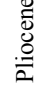 & \multicolumn{3}{|c|}{ Uvalde Gravel } & $0-20$ & $\begin{array}{l}\text { Loose pebbles, cobbles and gravels } \\
\text { often cemented with caliche }\end{array}$ & $\begin{array}{l}\text { Large gravels in areas of higher relief often } \\
\text { cemented with caliche }\end{array}$ & None & None & None & Fabric selective interparticle \\
\hline 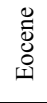 & 言 & \multicolumn{2}{|c|}{ Indio Formation } & $150-200$ & $\begin{array}{l}\text { Lenticular, thin-clay bed, gray to } \\
\text { buff sandstone, sandy shale }\end{array}$ & Thin beds of lignite and bog iron ore & None & None & None & Fabric selective interparticle \\
\hline \multirow{6}{*}{ 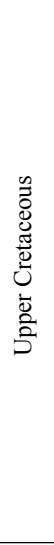 } & 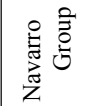 & \multicolumn{2}{|c|}{ Escondido Formation } & $200-875$ & $\begin{array}{l}\text { Fine-grained sandstone, with } \\
\text { interbedded shale, clay, and } \\
\text { pyroclastic material }\end{array}$ & $\begin{array}{l}\text { Brown, fine-grained sandstone, locally } \\
\text { fossiliferous }\end{array}$ & \multirow{6}{*}{ 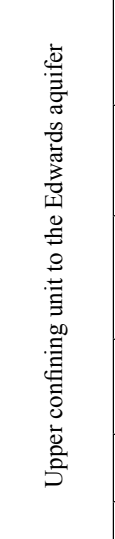 } & Confining unit & None & $\begin{array}{l}\text { Fabric selective interparticle; } \\
\text { nonfabric selective fractures }\end{array}$ \\
\hline & $\frac{\vec{b}}{\grave{d}}$ & Anacac & cho Limestone & 188 & $\begin{array}{l}\text { Massive mudstone to packstone, } \\
\text { with interbedded bentonitic clay }\end{array}$ & $\begin{array}{l}\text { White to gray packstone, with thick } \\
\text { sequences of bentonitic clays }\end{array}$ & & Confining unit & None & $\begin{array}{l}\text { Fabric selective moldic, } \\
\text { nonfabric selective fractures } \\
\text { and bedding plane }\end{array}$ \\
\hline & \multicolumn{3}{|c|}{ Austin Group } & 246 & $\begin{array}{l}\text { Massive, chalky to marly, } \\
\text { fossiliferous mudstone }\end{array}$ & $\begin{array}{l}\text { White, chalky limestone, with locally } \\
\text { abundant Gryphaea aucella, } \\
\text { Inoceramus sp. }\end{array}$ & & $\begin{array}{l}\text { Confining unit; aquifer } \\
\text { where connected to } \\
\text { Edwards by faults/ } \\
\text { fractures }\end{array}$ & $\begin{array}{l}\text { Minor along fracture/ } \\
\text { faults }\end{array}$ & $\begin{array}{l}\text { Fabric selective moldic, } \\
\text { nonfabric selective fractures } \\
\text { and bedding plane }\end{array}$ \\
\hline & \multicolumn{3}{|c|}{ Eagle Ford Group } & 71 & $\begin{array}{l}\text { Brown, flaggy, sandy shale and } \\
\text { argillaceous limestone }\end{array}$ & $\begin{array}{l}\text { Thin flagstones; petroliferous, fossil } \\
\text { fragments and fossils of Inoceramus sp. }\end{array}$ & & Confining unit & None & $\begin{array}{l}\text { Fabric selective interparticle, } \\
\text { nonfabric selective fractures } \\
\text { and bedding plane }\end{array}$ \\
\hline & \multirow{4}{*}{ 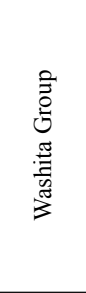 } & \multicolumn{2}{|c|}{ Buda Limestone } & 72 & Buff to light-gray, dense mudstone & $\begin{array}{l}\text { Porcelaneous limestone, iron nodules, iron } \\
\text { staining, iron replacement of fossils }\end{array}$ & & Confining unit & Minor surface karst & Nonfabric selective fractures \\
\hline & & \multicolumn{2}{|c|}{ Del Rio Clay } & 70 & Blue-green to yellow-brown clay & Fossiliferous; Ilymatogyra arietina & & Confining unit & None & Confining unit \\
\hline \multirow{8}{*}{ 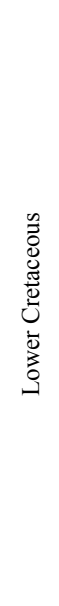 } & & ङै हี & Upper unit & 75 & $\begin{array}{l}\text { Wackestone that grades upward into } \\
\text { grainstone }\end{array}$ & $\begin{array}{l}\text { Light-gray wackestone to grainstone, with } \\
\text { abundant fossil fragments }\end{array}$ & \multirow{7}{*}{ 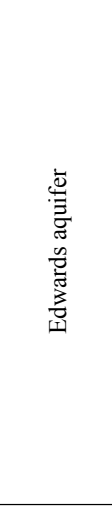 } & Aquifer & $\begin{array}{l}\text { Minor karst, associated } \\
\text { with solution- } \\
\text { enlarged fractures }\end{array}$ & $\begin{array}{l}\text { Nonfabric selective fractures, } \\
\text { bedding planes, caves }\end{array}$ \\
\hline & & 竡 & Lower unit & 340 & $\begin{array}{l}\text { Thick, massive lime mudstone, } \\
\text { grainstone, and chert }\end{array}$ & Massive, gray mudstone & & Aquifer & $\begin{array}{l}\text { Minor karst, associated } \\
\text { with solution- } \\
\text { enlarged fractures }\end{array}$ & $\begin{array}{l}\text { Fabric selective vug; nonfabric } \\
\text { selective fracture }\end{array}$ \\
\hline & \multirow{5}{*}{ 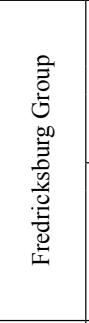 } & \multirow{4}{*}{ 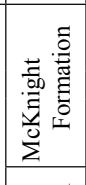 } & Upper unit & 120 & $\begin{array}{l}\text { Brownish, thin-bedded, pelleted, } \\
\text { mudstone to grainstone }\end{array}$ & $\begin{array}{l}\text { Brown, thin-bedded } \\
\text { mudstone to grainstone }\end{array}$ & & Aquifer & Negligible & $\begin{array}{l}\text { Fabric selective moldic, breccia; } \\
\text { nonfabric selective fractures }\end{array}$ \\
\hline & & & Middle unit* & * & $*$ & $*$ & & * & * & * \\
\hline & & & Lower unit* & $*$ & $*$ & $*$ & & * & * & * \\
\hline & & & Undivided* & * & * & * & & * & * & * \\
\hline & & 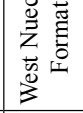 & $\begin{array}{l}\text { Basal } \\
\text { nodular } \\
\text { unit }\end{array}$ & 70 & $\begin{array}{l}\text { Nodular, burrowed mudstone } \\
\text { to wackestone miliolids, } \\
\text { gastropods, and Exogyra texana }\end{array}$ & $\begin{array}{l}\text { Nodular gray mudstone, black rotund } \\
\text { bodies }\end{array}$ & & $\begin{array}{l}\text { Confining unit; aquifer } \\
\text { where solutionally } \\
\text { enhanced }\end{array}$ & $\begin{array}{l}\text { Minor, primarily near } \\
\text { contact Trinity } \\
\text { aquifer }\end{array}$ & Nonfabric selective fractures \\
\hline & 总灾 & Glen R & ose Limestone & $900-1,530$ & $\begin{array}{l}\text { Tan, alternating layers of } \\
\text { medium-bedded limestone and } \\
\text { argillaceous limestone }\end{array}$ & $\begin{array}{l}\text { Stairstep topography, tan mudstones, marly, } \\
\text { thin bedded, Tylostoma sp., Turritella } \\
\text { sp., Protocardia texana }\end{array}$ & $\begin{array}{l}\text { Trinity } \\
\text { aquifer }\end{array}$ & $\begin{array}{c}\text { Confining unit to Edwards } \\
\text { aquifer; aquifer where } \\
\text { evaporite beds present }\end{array}$ & $\begin{array}{l}\text { Minor, associated with } \\
\text { solution-enlarged } \\
\text { fractures }\end{array}$ & $\begin{array}{l}\text { Fabric selective boxwork, } \\
\text { breccia, moldic; nonfabric } \\
\text { selective fractures and caves }\end{array}$ \\
\hline
\end{tabular}


Sayre (1936) observed recharge to the Edwards aquifer in Uvalde and Medina Counties occurs from stream losses and calculated an annual amount of recharge from these counties. Sayre (1936) also speculated that water was moving in the Edwards aquifer eastward from Medina County into Bexar County. Sayre (1942) made the fundamental observations on the regional extent of circulation within the Edwards aquifer and indicated that groundwater flow was regionally eastward through the confined aquifer from the recharge areas in Uvalde and Medina Counties to natural discharge sites at the major springs in Comal and Hays Counties. Welder and Reeves (1962) described the groundwater resources and mapped the geology of Uvalde County, reported that the principal structural feature is the Balcones Fault Zone with regional dip to the south-southeast of approximately 100 feet per mile, and delineated a prominent, subsurface structural high known as the Uvalde Salient. The western limit of the Knippa Gap was defined by Maclay and Land (1988) as the Uvalde Salient. Green and others (2006) reported on the water levels, structural geology, and water chemistry of the Edwards aquifer in Kinney and Uvalde Counties to develop an updated conceptual model of the groundwater system and to clearly define the relation between areas of groundwater storage in the Edwards aquifer of Uvalde and areas to the east.

\section{Methods of Investigation}

\section{Geologic Interpretation Methods}

Previous geologic maps and reports (Maclay and Land, 1988; Clark and Small, 1997; Clark, 2003; Clark and Journey, 2006; Smith and others, 2003) covering parts of Uvalde and Medina Counties were used as the starting point for documenting the geologic framework and hydrogeologic characteristics of the study area. Previous interpretations of the origin and age of the formations present in Uvalde and Medina Counties were applied to the study area. The surface geology was mapped by using stratigraphy and nomenclature of previous reports (Shumard, 1860; White and Hill, 1887; Dumble, 1892; Hill and Vaughn, 1898; Udden, 1907; Liddle, 1918; Trowbridge, 1923; Sayre, 1936; Wilmarth, 1938; Lozo and Smith, 1964; Barnes, 1974; Barnes, 1977; Miller, 1983). Helicopter electromagnetic survey (HEM) data (Smith and others, 2003, 2008) were used to help depict the geology and to aid in identifying faults.

Historical aerial photography acquired in 1954 (U.S. Department of Agriculture, 1954) was examined to observe vegetation and drainage patterns that might reveal possible changes in surficial geology, the locations of fractures and faults, and to identify any linear features that might reveal geologic structure (fig. 6). Visible surficial delineations of

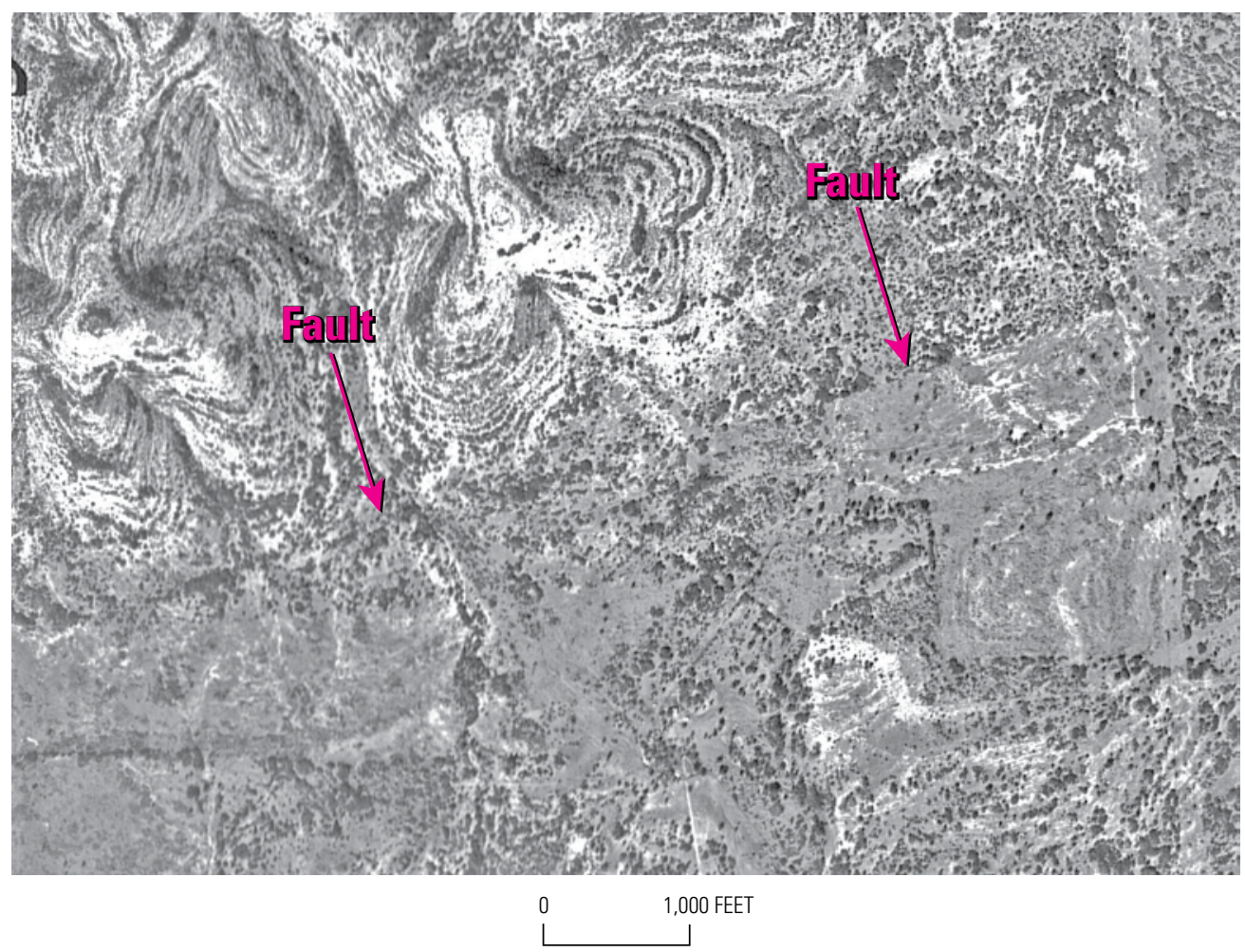

Figure 6. Aerial photograph showing a linear fault identified by the vegetation growing along its surface expression (U.S. Department of Agriculture, 1954). 
geologic features such as fractures and faults often contain denser vegetation compared to the adjacent terrain and can be identified from vegetation changes on aerial photographs (Singhal and Gupta, 1999). Figure 6 provides an example of a linear fault identified by the vegetation growing along its surface expression. Changes in rock type at formational contacts also can result in changes in vegetation. Figure 7 provides an example of circular bands of vegetation that correlate with isolated exposures of igneous rock in an area composed primarily of alluvium. Surficial features were traced from aerial photographs and transferred to USGS 1:24,000-scale 7.5-minute quadrangle topographic maps.

Historical borehole geophysical data were compiled for 174 wells in the study area (appendix 1). Formational contacts in the subsurface were identified where possible on the basis of changes in the natural gamma response evident from the geophysical logs. Changes in natural gamma typically indicate changes in the lithology and can be used to identify the tops and bases of the formations. The combined data then were digitized, and a feature class was developed representing the geology.

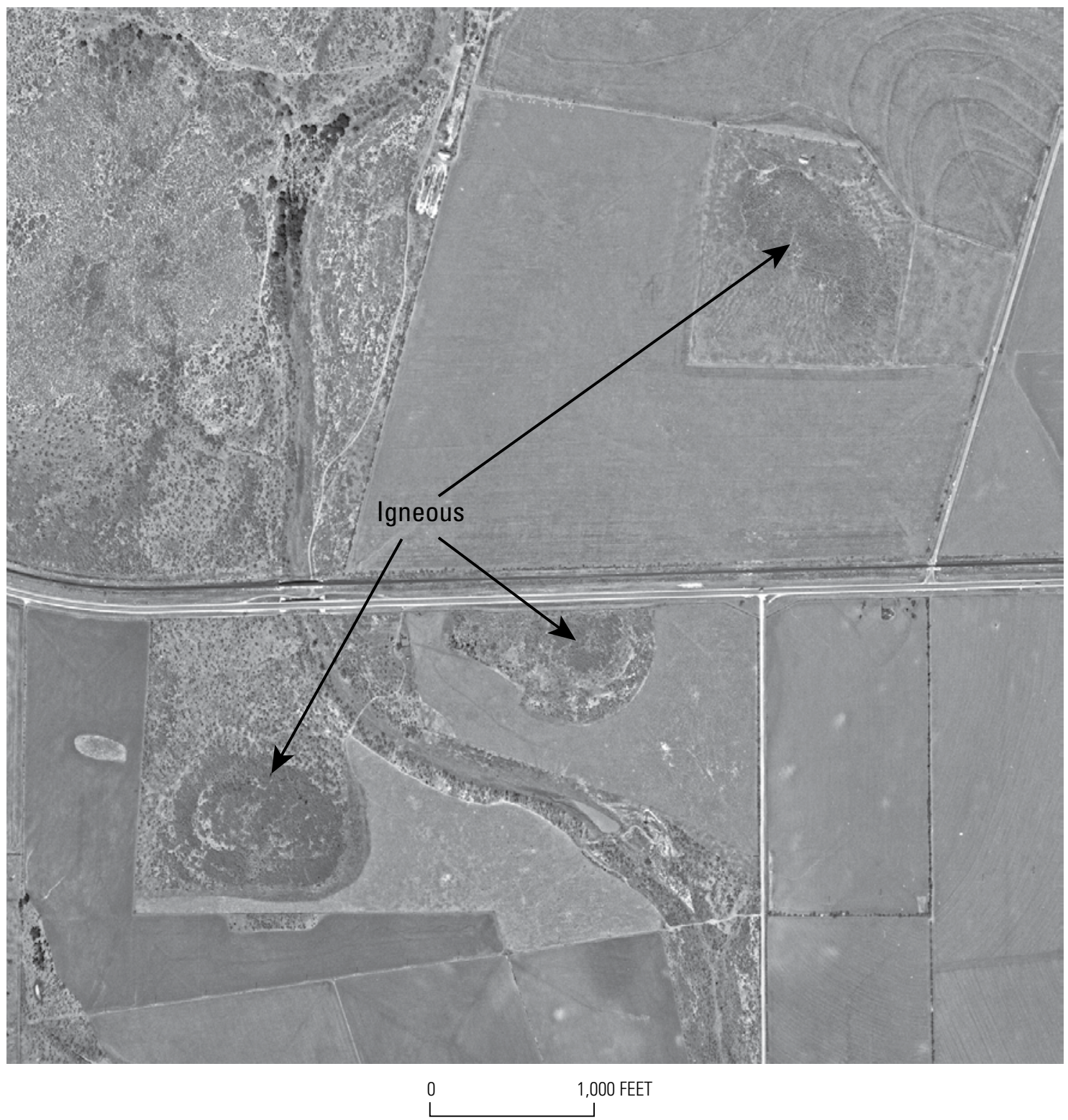

Figure 7. Aerial photograph showing circular bands of vegetation that correlate with isolated exposures of igneous rock in an area composed primarily of alluvium (U.S. Department of Agriculture, 1954). 
During January through August 2012, field mapping was done to further identify geologic contacts, thicknesses of exposed formations, and faults and fractures. The field mapping data were augmented with data obtained from previous reports, HEM surveys, aerial photographs, and historical borehole geophysical data. The geophysical data were historically collected by the USGS or obtained over many years from either the Texas Water Development Board or Edwards Aquifer Authority. Hardcopies of these data are maintained at the USGS office in San Antonio, Texas.

Compiled data were used to aid in the interpretation of features mapped in the field such as outcrops incised by a stream or offset by faulting. During field mapping, geologic and hydrogeologic features were identified, and the latitude, longitude, and altitude of contacts and faults were recorded by using hand-held Global Positioning System (GPS) units.

Dunham's (1962) carbonate-rock classification and Choquette and Pray's (1970) porosity classification systems were used to describe the rock outcrops. This approach is consistent with work done to describe rock outcrops by previous investigators in south-central Texas (Maclay and Small, 1984; Stein and Ozuna, 1995; Clark and Small, 1997; Clark, 2003; Blome and others, 2005). Dunham's (1962) carbonate-rock classification, based on the arrangement and ratio of fine to coarse sediments, was used to describe the facies, aspect, appearance, and characteristics of rock units, which usually reflect the diagenesis of its origin (Bates and Jackson, 1987). The porosity classifications of Choquette and Pray (1970) were used to characterize the porosity as fabric selective or nonfabric selective. Fabric selective porosity is secondary porosity that preferentially developed along specific sedimentary structures, strata, or mineralogy (Choquette and Pray, 1970). Moldic porosity is an example of fabric selective porosity; moldic porosity was formed where shell material dissolved, leaving a void. Nonfabric selective porosity is secondary porosity that developed without the influence of sedimentary structures and is not associated with the original sedimentary or diagenetic processes but is caused by other geologic processes such as fracturing and faulting (Choquette and Pray, 1970). Vug porosity, which formed as a result of the diagenetic process, is an example of nonfabric selective porosity.

\section{Geodatabase Development and Data Management}

The data collected and plotted on USGS 1:24,000scale 7.5-minute quadrangle topographic maps during the field mapping were scanned, merged, and digitized to create a Geographic Information System (GIS) data layer covering the study area. All GIS data were geo-referenced to a Universal Transverse Mercator (UTM) projection using North American Datum of 1983 (NAD 83).

To manage the data collected or complied for the study, a geodatabase was developed for project use. A geodatabase is a collection of spatial and tabular data that allows users to associate data with physical and spatial features (Zeiler, 1999). The geodatabase is composed of four core database objects: feature datasets, feature classes, relation classes, and attribute tables. Feature classes in the geodatabase are spatial layers of similar vector type data (point, line, or polygon). A feature dataset manages a grouping of feature classes and uses a defined geographic or projected coordinate system for all the data managed and grouped under the feature dataset. Relation classes allow for data stored in feature classes to be linked with tabular information stored in attribute tables. The geodatabase for this study was based on the Environmental Systems Research Institute (ESRI) ArcGIS 10.0 personal geodatabase platform (Environmental Systems Research Institute, Inc., 2013).

The project geodatabase includes a single feature dataset containing geospatial data that describes the surface geology for the study area. The Surface_Data feature dataset contains five feature classes that spatially represent the study area boundary, mapped geology, faults, wells, and geologic crosssection traces. In addition, there are two attribute tables (tbl GeologyInfo and tbl_WellInfo) that contain well and geologic information and are associated with the well feature class. The attribute tables are linked to the well feature class by relation classes based on the well identification field. To uniquely identify each well, wells were assigned a State well number using the Texas Water Development Board (TWDB) Ground Water Data System (Nordstrom and Quincy, 1999). Some wells were missing a complete State well number and were assigned two to three characters at the end of the well number sequence to distinguish wells from other wells (appendix 1). Well and borehole geophysical information were compiled from hardcopy files or downloaded from existing digital databases hosted by various Federal, State, and local agencies.

An interactive approach can be taken to explore these data in the geodatabase when using GIS or through traditional database queries. In GIS, these data can be viewed spatially and in combination with other relevant geospatial data layers such as aerial imagery, administrative boundaries, and hydrography. The data can also be analyzed spatially in GIS to aid in identifying distribution patterns, data gaps, spatial relations, and to create cartographic products.

Data formats and database schemas from different source agencies are not structured the same, so the final geodatabase schema was structured to capture only pertinent information related to the study. Queries were done on well entry records to identify duplicate records based on well number, geographic location, or both. Simple cross-check queries were performed to ensure the number of records between related tables remained consistent. The data and metadata created for use in this study conform to Federal Geographic Data Committee (FGDC) standards (Federal Geographic Data Committee, 2012). The metadata document and describe the contents of the geodatabase such as title, abstract, publication date, author, geographic extent, projection information, process steps, and attribute label definitions. Metadata were reviewed by using the USGS Geospatial Metadata Validation Service (U.S. Geological Survey, 2013) and by USGS personnel. 


\section{Geologic Framework, Structure, and Hydrogeologic Characteristics}

By using all of the data that were compiled and collected for this study, a map (pl. 1) was constructed depicting the geologic framework, structure, and hydrogeologic characteristics of the Knippa Gap area in eastern Uvalde and western Medina Counties, Tex. Part A of plate 1 is a geologic map depicting the geologic formations in the study area (excluding gravel deposits, which were plotted separately in part B of plate 1), overlain with contacts between formations, faults, fractures, and facies changes. The inferred structural dip is also featured in part A of plate 1, and the location of the Knippa Gap structural low (trough) is delineated. Hydrogeologic cross-sections $\mathrm{A}-\mathrm{A}^{\prime}$ and $\mathrm{B}-\mathrm{B}^{\prime}$ are identified, along with the locations of wells from which borehole geophysical data were obtained.

Gravel deposits are shown in part B of plate 1 without the underlying geology in order to highlight the amount of the study area that is covered by the gravels. The gravel covered land surface historically has been an obstacle for analyzing the geology and structure of the Knippa Gap area.

The major hydrogeologic feature of the study area, the San Antonio segment of the Edwards aquifer, is depicted in part $\mathrm{C}$ of plate 1 . The approximate downdip limit of the freshwater zone (Schultz, 1994) of the Edwards aquifer is shown.

The two hydrogeologic cross sections (parts D and E of plate 1) were constructed by using the geophysical borehole data compiled for the study. Part D of plate 1 depicts hydrogeologic cross-section $\mathrm{A}-\mathrm{A}^{\prime}$, which trends southwest to northeast across the study area. Part $\mathrm{E}$ of plate 1 depicts hydrogeologic cross-section B-B', which trends northwest to southeast across the study area. The locations of the wells used to construct each hydrogeologic cross section are included, and vertical faults are delineated as well as the Edwards aquifer at depth.

\section{Geologic Framework}

In eastern Uvalde and western Medina Counties, sedimentary rocks from the Lower Cretaceous to the Pleistocene are exposed, along with intrusive igneous rocks of Upper Cretaceous age (Smith and others, 2003). The sedimentary rocks are composed of limestone, chalk, gravel, sand, silt, shale, and clay. The igneous rocks are ultramafic to intermediate in composition (Lonsdale, 1927; Sellards, 1932). Volcanic activity during the Cretaceous period resulted in pyroclastic deposits and basaltic flows (Lonsdale, 1927; Sellards and others, 1932) in the study area.

\section{Lower Cretaceous Series}

The Glen Rose Limestone is part of the Trinity Group (figs. 4-5) and was deposited during the Lower Cretaceous period. According to Miller (1984), the Glen Rose Limestone unconformably underlies the Devils River Formation (pl. 1, fig. 4) in the Devils River Trend (fig. 2) in the eastern part of the study area and conformably underlies the West Nueces Formation in the Maverick Basin (fig. 2) in the western part of the study area. The Glen Rose Limestone varies in thickness from approximately $900 \mathrm{ft}$ to approximately $1,530 \mathrm{ft}$ in Uvalde County (Welder and Reeves, 1962) and is composed mostly of alternating layers of limestone and argillaceous limestone.

The Lower Cretaceous Devils River Formation (fig. 4) was unconformably deposited over the Glen Rose Limestone (Miller, 1984). In the study area, the total thickness of the Devils River Formation was calculated to be approximately $600 \mathrm{ft}$ based on geophysical logs and is composed primarily of miliolid, pellet, rudist, shell-fragment, lime grainstone and wackestones locally dolomitized, brecciated, and chert bearing (Lozo and Smith, 1964). The limestone is also locally dolomitized, brecciated, and chert bearing (Lozo and Smith, 1964).

The Devils River Formation lacks sufficient marker beds that effectively preclude a more detailed, regional subdivision, or differentiation (Lozo and Smith, 1964) other than the regionally extensive basal unit of mixed sediments informally referred to as the basal nodular member (Miller, 1984; Clark, 2003) and an informal recognition of lower and upper parts of the Devils River Formation (Collins, 2000).

The regional basal nodular member (figs. 4-5), which is approximately $20-70 \mathrm{ft}$ thick, is a distinctively nodular, burrowed, sequence of dolomitic mudstone to wackestone (Clark, 2003) in the Devils River Formation (fig. 4) and West Nueces Formation (fig. 5). The basal nodular member contains miliolids, gastropods, and the pelecypod Exogyra texana. The basal nodular member is overlain by a burrowed unit (Miller, 1984) that contains a thin- to massive-bedded mudstone to grainstone, approximately $30-40 \mathrm{ft}$ thick, and is named for its distinctive massive, resistant layers of porous, burrowed limestone (Rose, 1972). The mudstone becomes more thickly bedded and less burrowed progressively upward through the unit. Above the burrowed unit thickness of the dolomitic unit is approximately $260 \mathrm{ft}$, and is a wackestone to grainstone, containing miliolid, shell fragments, and gastropods. In addition, the dolomitic unit lithologically ranges from shellfragmented, mudstone to wackestone, and beds of rudist and small rudist bioherms are common (Miller, 1984). Chert, which first occurs approximately $20 \mathrm{ft}$ above the basal nodular member, can be found as nodules or beds throughout the Devils River, West Nueces, McKnight, and Salmon Peak Formations (figs. 4-5) (Rose, 1972).

The upper $270 \mathrm{ft}$ of the Devils River Formation consists of light-gray wackestone, packstone, miliolid grainstone, and rudist boundstone. Rudists, shell fragments, chert nodules, and thin chert beds are scattered throughout and are commonly abundant (Miller, 1984). Caprinid fossils, along with other varieties of rudists, are present locally, commonly form boundstone, and have often been replaced by chert (Miller, 1984).

The edges of the western part of the study area coincide with the eastern limit of the Maverick Basin. The formations 
within the Maverick Basin are the West Nueces, McKnight, and Salmon Peak Formations (fig. 5) (Lozo and Smith, 1964). In the study area, only the basal nodular member of the West Nueces Formation, the upper part of the McKnight Formation, and the Salmon Peak Formation are present (pl. 1, fig. 5). The upper part of the West Nueces, lower part of the McKnight Formation, and the middle part of the McKnight Formation are not present in the study area because of changes in the shape of the Maverick Basin during the depositional sequence.

The only part of the West Nueces Formation present in the study area is the 70-ft thick (Clark, 2003) basal nodular member (pl. 1, fig. 5). As in other areas, the basal nodular member of the West Nueces Formation is a distinctively nodular, burrowed mudstone to wackestone (Miller, 1984) containing miliolids, gastropods, and the Exogyra texana (Clark, 2003).

According to Miller (1984), the McKnight Formation, which overlies the West Nueces Formation, can be subdivided into informal lower, middle, and upper units (fig. 5). The lower and middle units are not present in the study area but are included in figure 5 to help in understanding the complex depositional history of the area.

In surface exposures approximately 20 miles (mi) west-northwest of the northern boundary of the study area, the upper McKnight unit (fig. 5) is approximately $120 \mathrm{ft}$ thick. The upper McKnight is composed of brownish, thinbedded, pelleted mudstone to grainstone. The contact between the upper McKnight unit and the overlying Salmon Peak Formation is gradational and conformable. A conglomeratic zone, consisting of bored rip-up clasts, lies just below the Salmon Peak Formation (Lozo and Smith, 1964). Lozo and Smith (1964) believed this horizon of rip-up clasts represented a gap in deposition at the base of the Salmon Peak Formation.

The lower part of the Salmon Peak Formation (fig. 5) is up to $340 \mathrm{ft}$ thick in the Maverick Basin and consists mostly of thick-bedded to massive pelagic-derived mudstones that grade [shoal] upward into a crossbedded, rudist shell grainstone containing chert in the upper $165 \mathrm{ft}$ (Lozo and Smith, 1964; Humphreys, 1984). The upper unit of the Salmon Peak Formation is up to $75 \mathrm{ft}$ thick in the Maverick Basin and consists mostly of grainstones and wackestones with bioclastic grainstones near the top part.

\section{Upper Cretaceous Series}

In the study area, the Del Rio Clay, Buda Limestone, Eagle Ford Group, Austin Group, Anacacho Limestone, and Escondido Formations (pl. 1, figs. 4-5) were deposited during the Upper Cretaceous. The sedimentary units are composed of shale, clay, sand, limestone, and igneous pyroclastic/detrital material. The Upper Cretaceous age igneous rocks that are common in the study area are both intrusive and extrusive types (Ewing and Barker, 1986).

The Del Rio Clay of the Washita Group (pl. 1, figs. 4-5) directly overlies the Lower Cretaceous formations in Uvalde and Medina Counties. In the study area, the Del Rio Clay is approximately $70 \mathrm{ft}$ thick (based on data from 153 wells in the study area) and consists of mostly dark blue-green and yellow-to-brown clay with thin beds of impervious limestone. Iron nodules are locally abundant and the index fossil Ilymatogyra arietina (fig. 8) is abundant throughout. Secondary gypsum commonly occurs as fracture fillings in Del Rio Clay outcrops near igneous bodies. Exposures of the Del Rio Clay are found north of Uvalde and adjacent to U.S. Highway 83 (fig. 1). The contact between the Del Rio Clay and the overlying Buda Limestone (pl. 1, figs. 4-5) is distinct and easily recognized, with the Buda Limestone blocks slumping (fig. 9) down the hillsides over the Del Rio Clay outcrops.

The thickness of the Buda Limestone of the Washita Group averages $72 \mathrm{ft}$ in the study area based on data from 106 well logs. The Buda Limestone is a buff to light-gray, dense mudstone, weathering from a smooth gray to a grayishwhite, nodular surface exhibiting smooth conchoidal fractures (Adkins, 1932; Clark, 2003). In the study area, the formation commonly contains iron nodules, iron staining, and fossils replaced by iron. The lower contact of the Buda Limestone with the Del Rio Clay is unconformable as is the upper contact of the Buda Limestone with the Eagle Ford Group (Martin, 1967) (pl. 1, figs. 4-5). Bored rip-up clasts of Del Rio Clay can be found in the lower few inches of the Buda Limestone (Kittenbrink, 1983) located north of Uvalde; however, these clasts are not common.

The Eagle Ford Group (pl. 1, figs. 4-5) is approximately $71 \mathrm{ft}$ thick in the study area, based on 72 well logs and field mapping in 2012 by the authors. The Eagle Ford Group consists of brown, flaggy, sandy shale and argillaceous limestone (Trevino, 1988). In the study area, this Group contains fossil fragments and fossils of Inoceramus sp. Some of these freshly fractured flagstones emit a petroliferous odor. The upper contact with the overlying Austin Group (pl. 1) is gradational. According to Freeman (1961), there is a transitional zone of up to $5 \mathrm{ft}$ in thickness where the Eagle Ford Group beds resemble the Austin Group.

The Austin Group (pl. 1, figs. 4-5, fig. 10) is approximately $246 \mathrm{ft}$ thick in the study area based on the average thicknesses recorded on 45 well logs. The Austin Group consists of massive, chalky, locally marly, generally fossiliferous mudstone that commonly contains the fossil oyster Gryphaea aucella, and Inoceramus sp. (figs. 4-5, fig. 11). Field observations indicate that Austin Group outcrops located near igneous bodies are commonly a grainstone with reworked pyroclastic or detrital igneous material, abundant fossil fragments, iron nodules, and fractures. The fractures often contain void-filling calcite, sometimes in the form of dogtooth spar. In many areas, the Austin Group and the Anacacho Limestone are indistinguishable, probably because the two units were deposited contemporaneously, resulting in a lateral gradation. In addition, these two units were likely modified by igneous activity, which possibly heated the limestones (Clark and Small, 1997). 


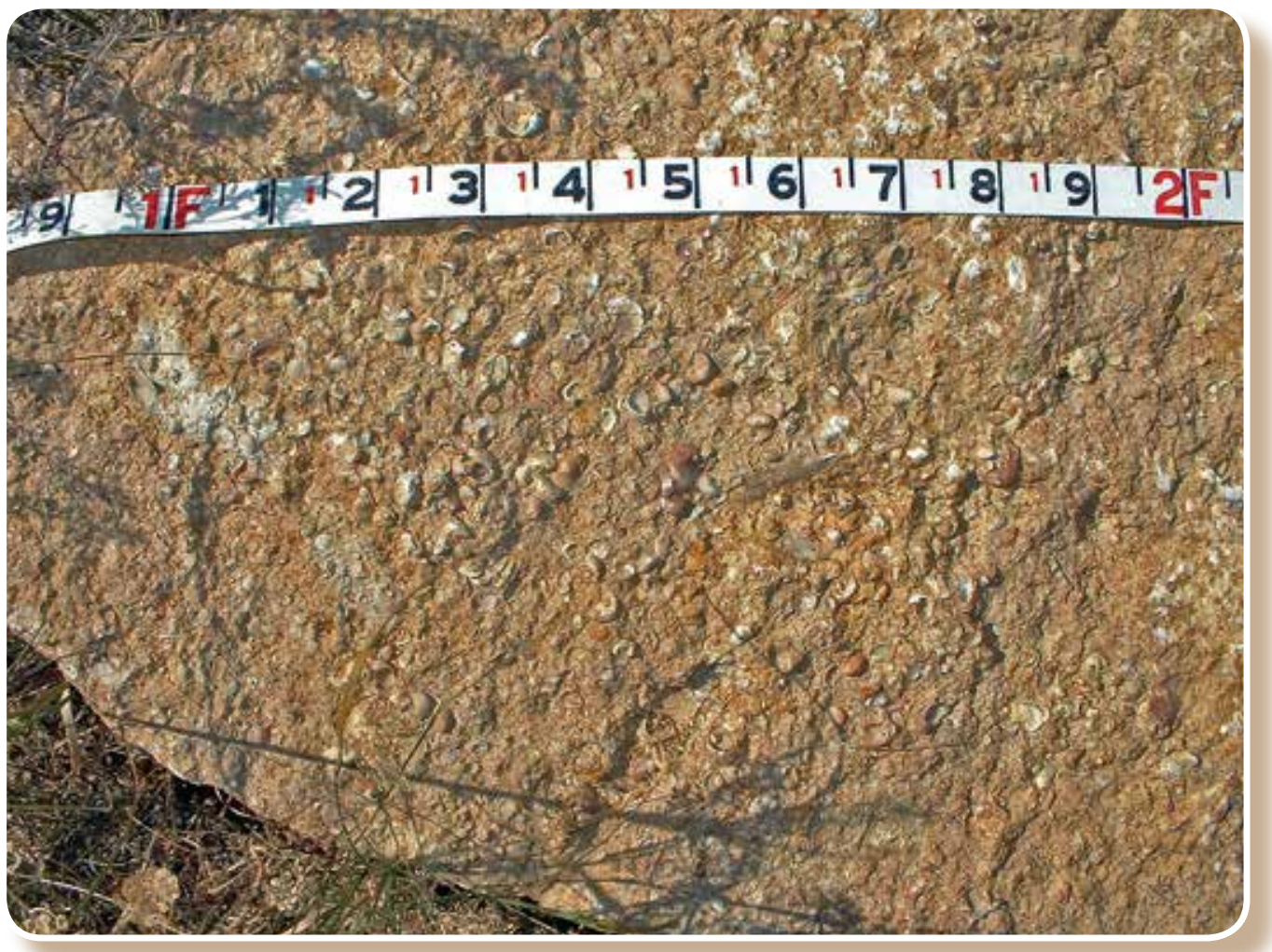

Figure 8. The abundance of llymatogyra arietina in the Del Rio Clay located in northeastern Uvalde County, Texas. Photograph taken April 23, 2012.

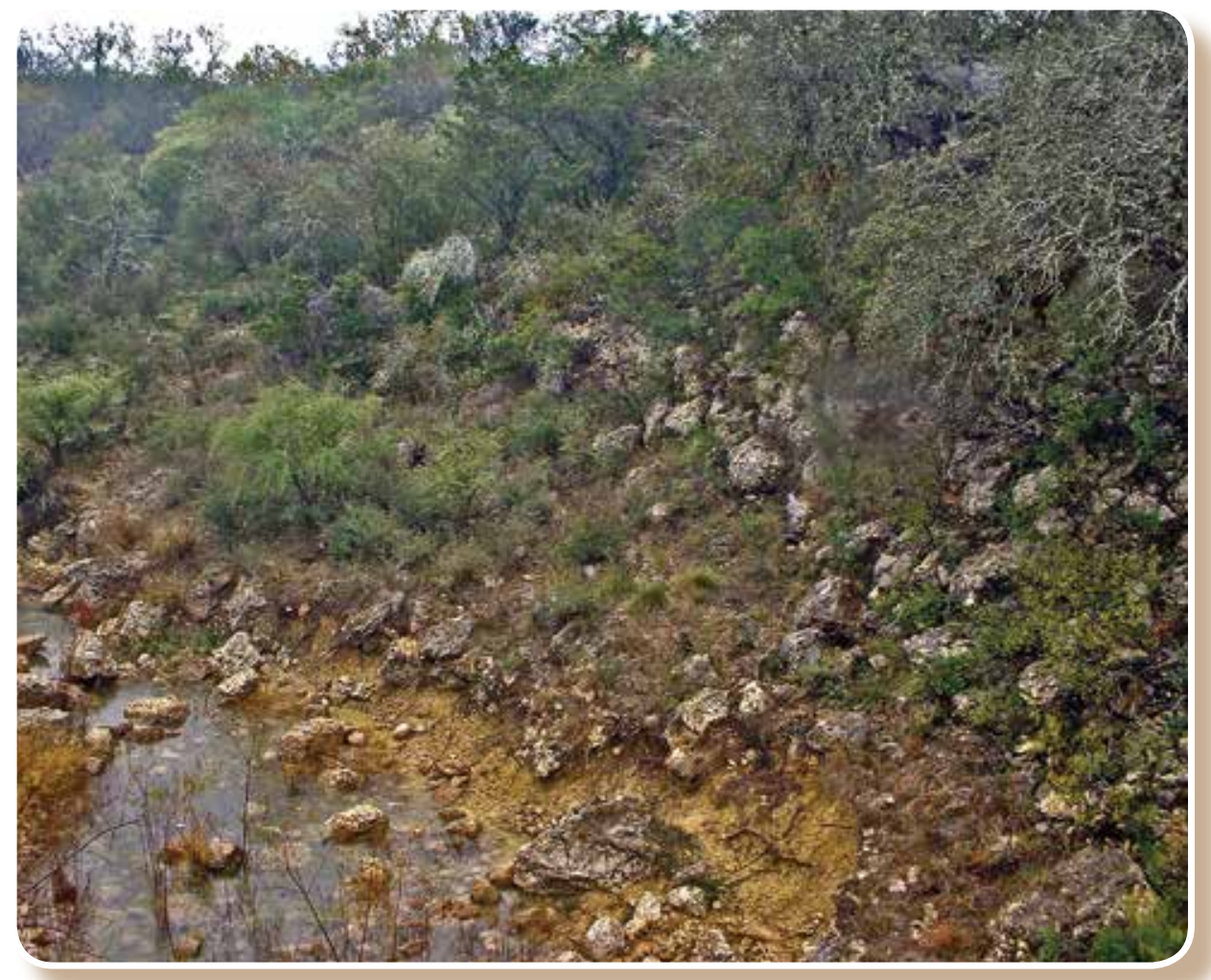

Figure 9. Contact between Buda Limestone (hillside) and Del Rio Clay (bed of creek) located on the west side of bridge at tributary to Seco Creek in northwestern Medina County, Texas. Photograph taken December 13, 2011. 


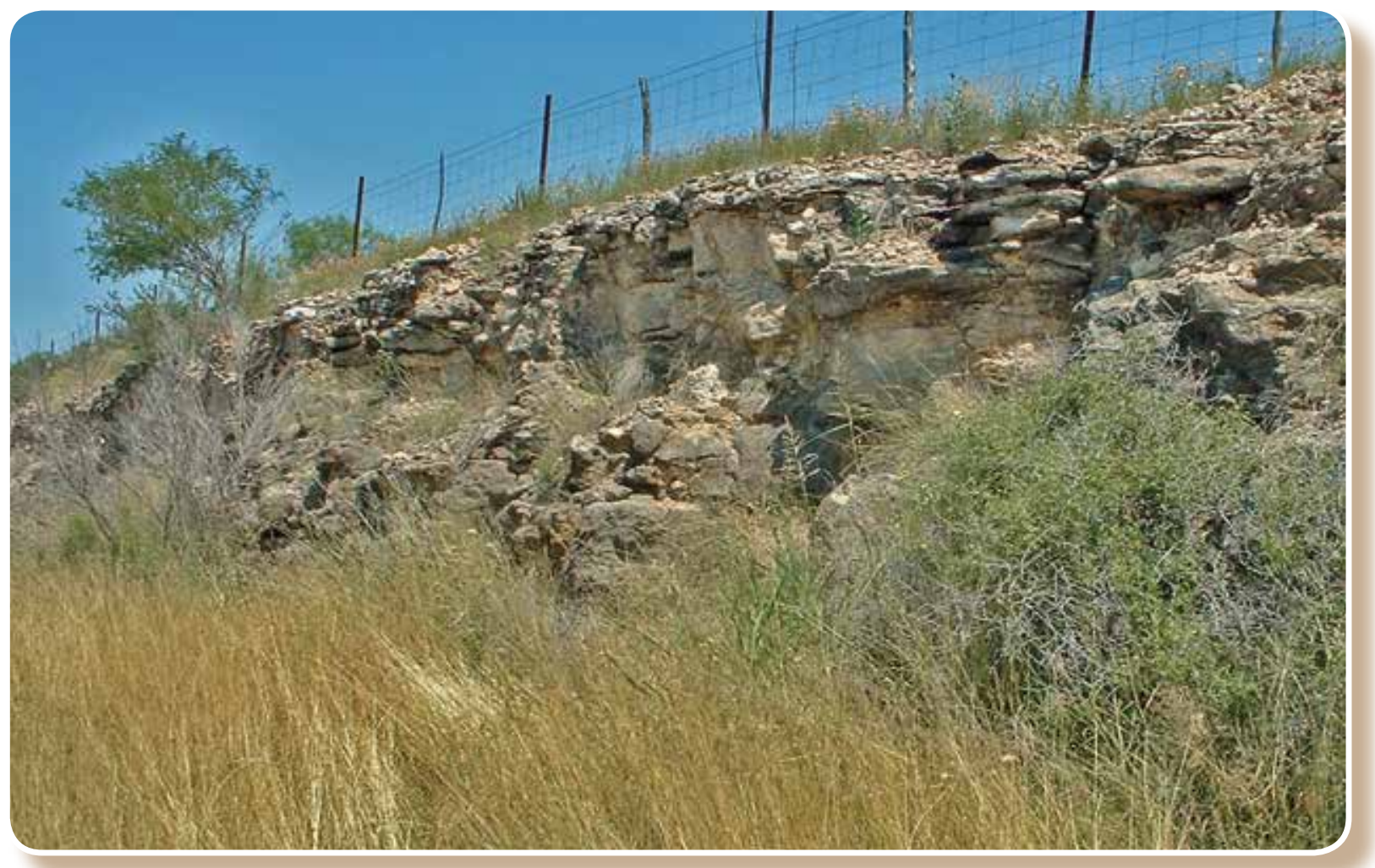

Figure 10. Exposed Austin Group in road cut excavation located on south side of U.S. Highway 90 and approximately midway between Sabinal and Knippa Texas, eastern Uvalde County, Tex. Photograph taken May 29, 2012.

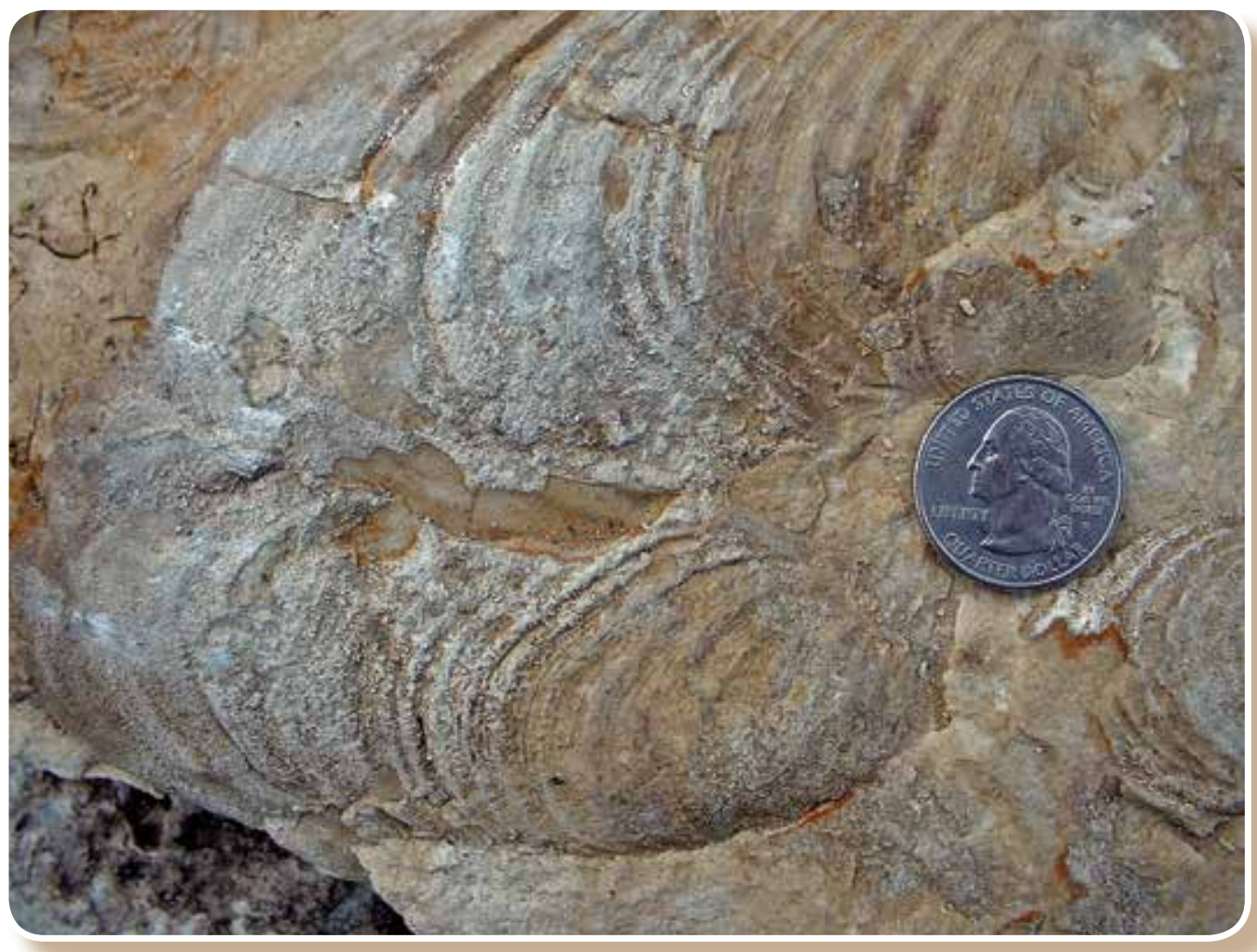

Figure 11. Inoceramus sp. fossil that is typical of the Austin Group located in the bed of the Leona River approximately 3 miles southsoutheast of city of Uvalde in Uvalde County, Texas. Photograph taken January 12, 2012. 
Contemporaneous with Upper Cretaceous igneous activity was the development of fringing reefs around the volcanoes or uplifts caused by intrusion of the igneous material (Luttrell, 1977). According to Wilson (1983), these fringing reefs represent patchy biostromes on bathymetric highs and atoll reefs or bank deposits around seamounts caused by the igneous intrusions. According to Ewing (2011), the fringing reefs coalesced into regional sheets and formed the Anacacho Limestone (pl. 1, figs. 4-5) that interfingers with and overlies the Austin Group in the study area. The Anacacho Limestone is a massive mudstone to packstone with interbedded bentonitic clay (Welder and Reeves, 1962; Clark, 2003) having an average thickness of $188 \mathrm{ft}$ in the study area based on logs from 22 wells.

According to Hazzard (1956), the lower part of the Anacacho Limestone contains beds that are rusty-red and clay-rich, which probably indicates the presence of waterlain pyroclastics. Hazzard (1956) also states that some of the limestone beds are coquina. The formation contains heavy oil/ asphalt that has been mined west of the city of Uvalde since 1891 (Getzendaner, 1931). In the study area, the Anacacho Limestone and all underlying formations are intruded or cut by igneous rocks.

The Escondido Formation (pl. 1, figs. 4-5, fig. 12) conformably overlies the Anacacho Limestone, is between $200 \mathrm{ft}$ and $875 \mathrm{ft}$ thick in the study area (Barnes, 1977), and consists of fine-grained, friable, calcareous, and argillaceous sandstone, with interbedded shale, clay, and pyroclastic material (Welder and Reeves, 1962). Ewing (2011) states "This formation contains a thick set of resistive sandstones [in geophysical logs] in the heavy oil province, perhaps forming a shoreline or wave-dominated delta sequence (see Pisasale, 1980). Asphaltic sandstones of the Escondido Formation crop out along the Nueces River in southern Uvalde and northernmost Zavala Counties."

\section{Upper Cretaceous Series Igneous Rocks}

Upper Cretaceous magmatic activity (Miggins and others, 2004) resulted in the emplacement of numerous and widely scattered igneous bodies from intrusive (dikes, sills, stocks, plugs, and possibly laccoliths) and extrusive (submarine and possible subaerial volcanoes) events (pl. 1, fig. 13) (Sellards and others, 1932; Smith and others, 2008). The igneous bodies intrude all of the Cretaceous age formations in the study area (Sellards and others, 1932). The Uvalde igneous field consists of fine- to coarse-grained, ultramafic and hypabyssal rocks (Miggins and others, 2004). Igneous activity might have been accompanied by pyroclastic events and lava flows (Ewing and Barker, 1986). These igneous bodies usually have columnar jointing, which forms perpendicular to the cooling surface (fig. 14). Recent radiogenic dating identifies two distinct phases of magmatic activity. The first phase of intrusions occurred approximately $82-80$ million years ago, and the second phase, consisting of phonolites, occurred approximately 74-72 million years ago (Miggins and others, 2004).

The igneous activity was probably caused by changes in mantle-convection regimes (Ewing and Barker, 1986), from compressional forces associated with the Laramide orogeny (Ewing, 1991), or a combination thereof. Any of the factors could have reactivated zones of weakness in the underlying Ouachita Structural Belt (fig. 2) (Wilson, 1977). The Ouachita Structural Belt formed during the late Paleozoic collision of two continents (Poole and others, 2005). Regardless of the exact process, this igneous activity caused a regional uplift that is locally referred to as the Uvalde Salient (Welder and Reeves, 1962), and resulted in the subaerial exposure of igneous rocks during the Upper Cretaceous time (Ewing and Barker, 1986). According to Ewing and Barker (1986), the area of volcanic activity forms the axis of the Uvalde Salient referred to as the "Frio River Line." The "Frio River Line" is not shown on the map. The igneous rocks are not shown on figures $4-5$ because they penetrate, and are present, in all of the rocks stratigraphically below the Escondido Formation.

\section{Eocene Rocks}

The Indio Formation (pl. 1, fig. 5) unconformably overlies the Escondido Formation and is between 150 and 200 $\mathrm{ft}$ thick according to Welder and Reeves (1962). Welder and Reeves (1962) further state the Indio Formation is nonmarine in origin, was deposited in streams or deltas (Sellards and others, 1932), and contains lenticular, thin-bedded clay, sandy shale, and grey to buff sandstone. In some locations, the formation contains lignite and bog iron ore. Generally, the sandstone is friable and poorly cemented, but in some locations, the Formation contains better carbonate cement with cross bedding (Welder and Reeves, 1962).

\section{Pliocene to Pleistocene Series Rocks}

The Pliocene- to Pleistocene-age Uvalde Gravels and Leona Formation (pl. 1, figs. 4-5) (Sellards and others, 1932) were produced by the erosion of the Edwards Plateau. These units are present at the surface in most of the study area (Barnes, 1974).

The Uvalde Gravels (fig. 15) are Pliocene- to Pleistoceneage (Sellards and others, 1932) and commonly occur as a veneer of sediments at the land surface and rarely exceed $20 \mathrm{ft}$ in thickness (Barnes, 1974). The Uvalde Gravels were deposited by streams flowing from the Edwards Plateau with the fine-grained material being removed by subsequent winnowing (Sayer, 1936). The remaining gravels are loose pebbles, cobbles, or gravels. Some of the gravels are weakly cemented by caliche (Sayre, 1936; Welder and Reeves, 1962). After deposition, structural uplift, and ongoing erosion in the area caused dissection of the Uvalde gravels, which left the gravels topographically higher compared to the base of the current stream channels (Barnes, 1974). 


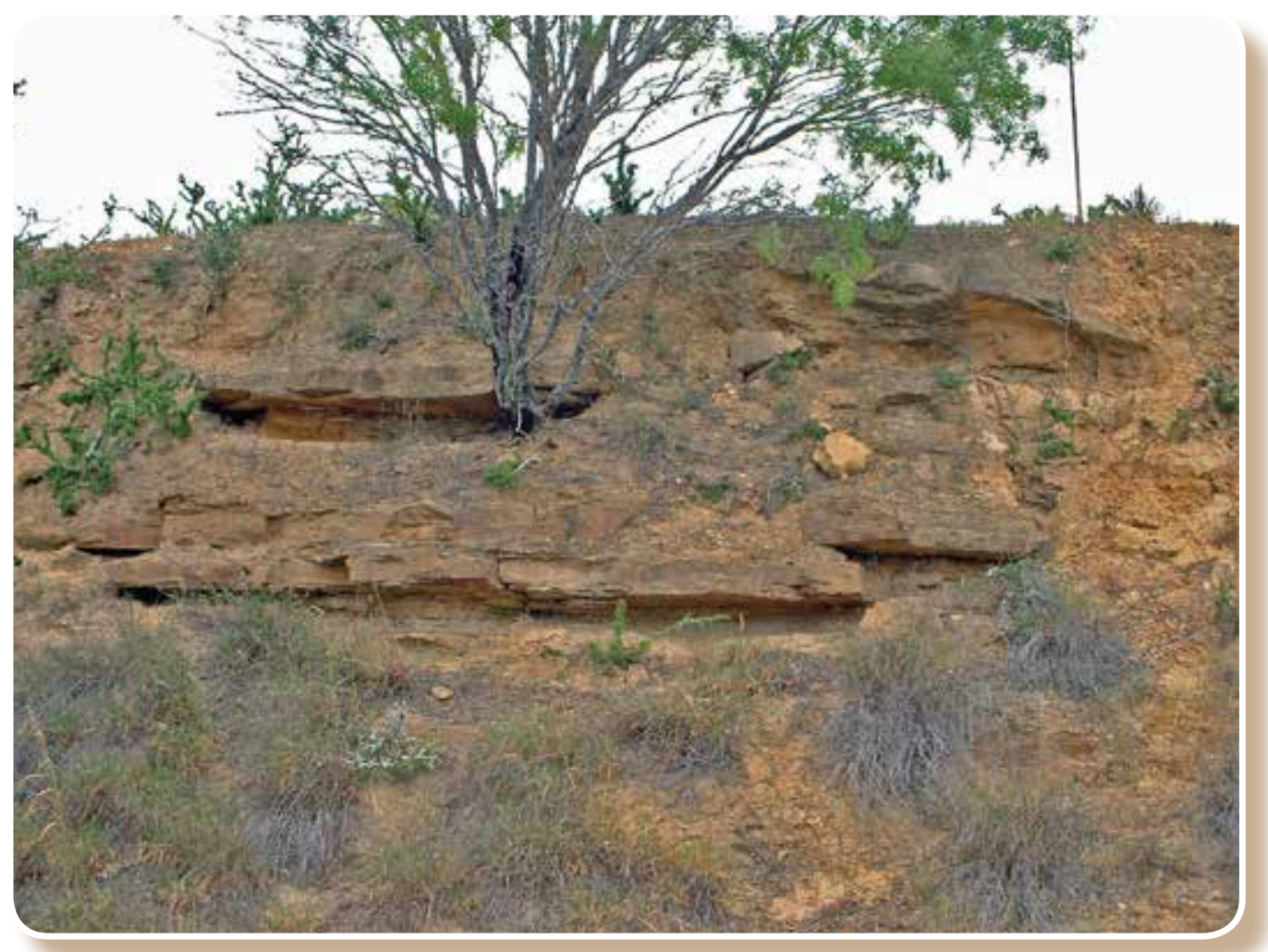

Figure 12. Sandstone ledges in the Escondido Formation located approximately 7 miles south-southeast of the community of D'Hanis in Medina County, Texas. Photograph taken April 13, 2012.

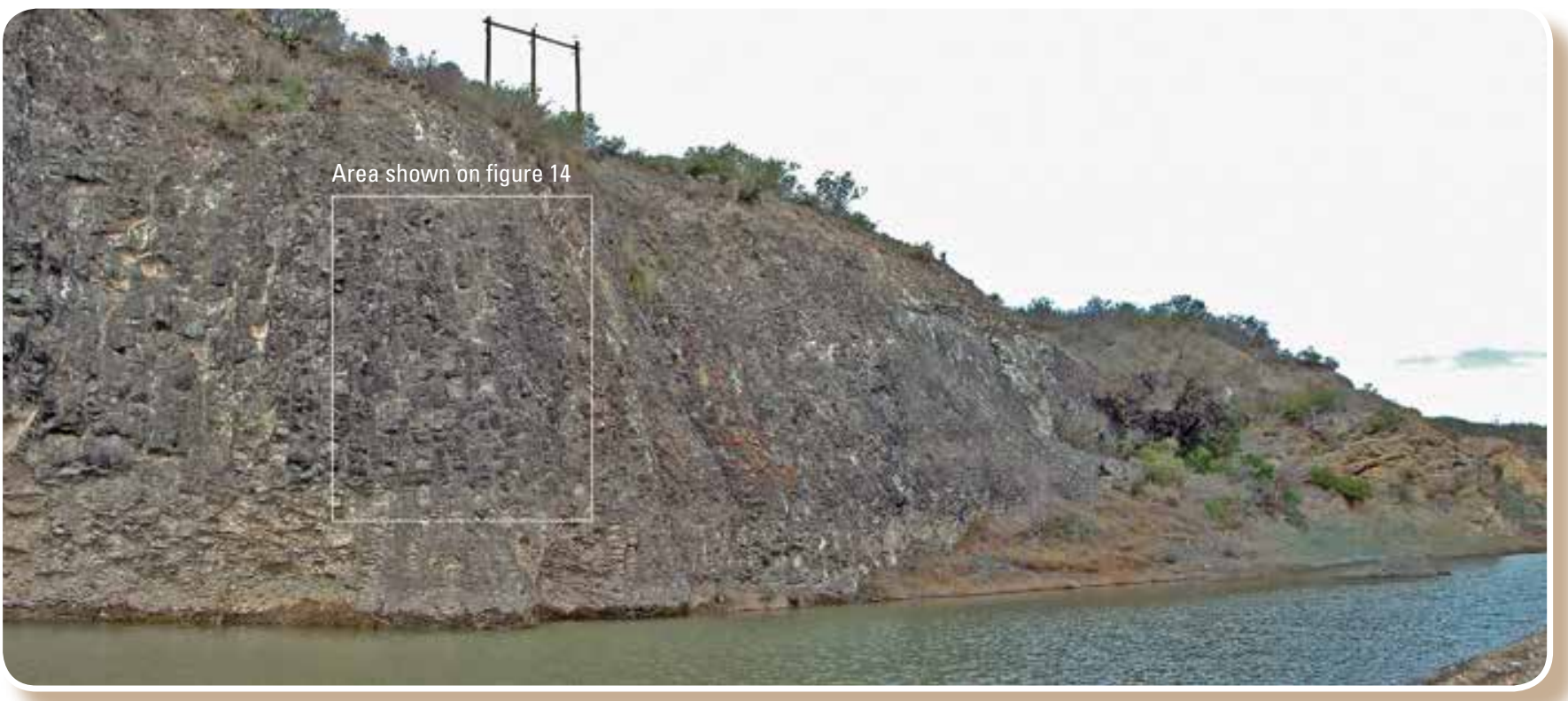

Figure 13. Outcrop of eroded and dissected extinct volcano located adjacent to the Frio River and east of the city of Uvalde in Uvalde County, Texas. Basalt is remnant of volcanic neck, and adjacent to the basalt is pyroclastic material ranging from fine-grained material to volcanic bombs, which formed the slope of the volcano. Photograph taken January 12, 2012. 


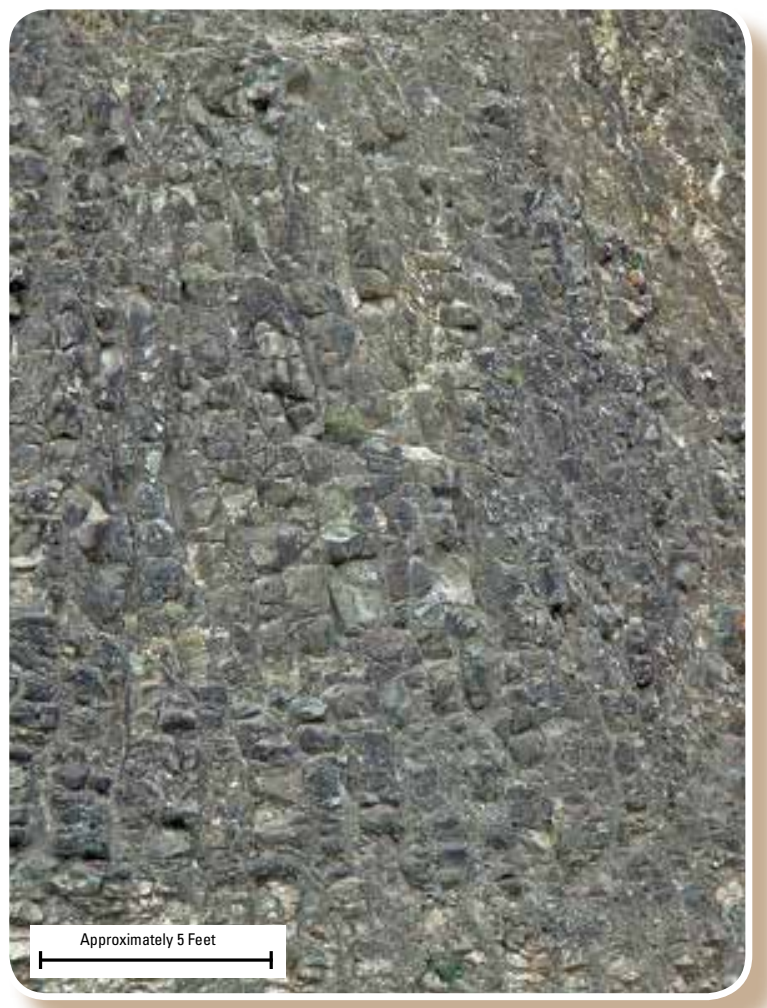

Figure 14. Columnar jointing common in igneous rocks located adjacent to the Frio River and east of the city of Uvalde in Uvalde County, Texas. Photograph taken January 12, 2012.

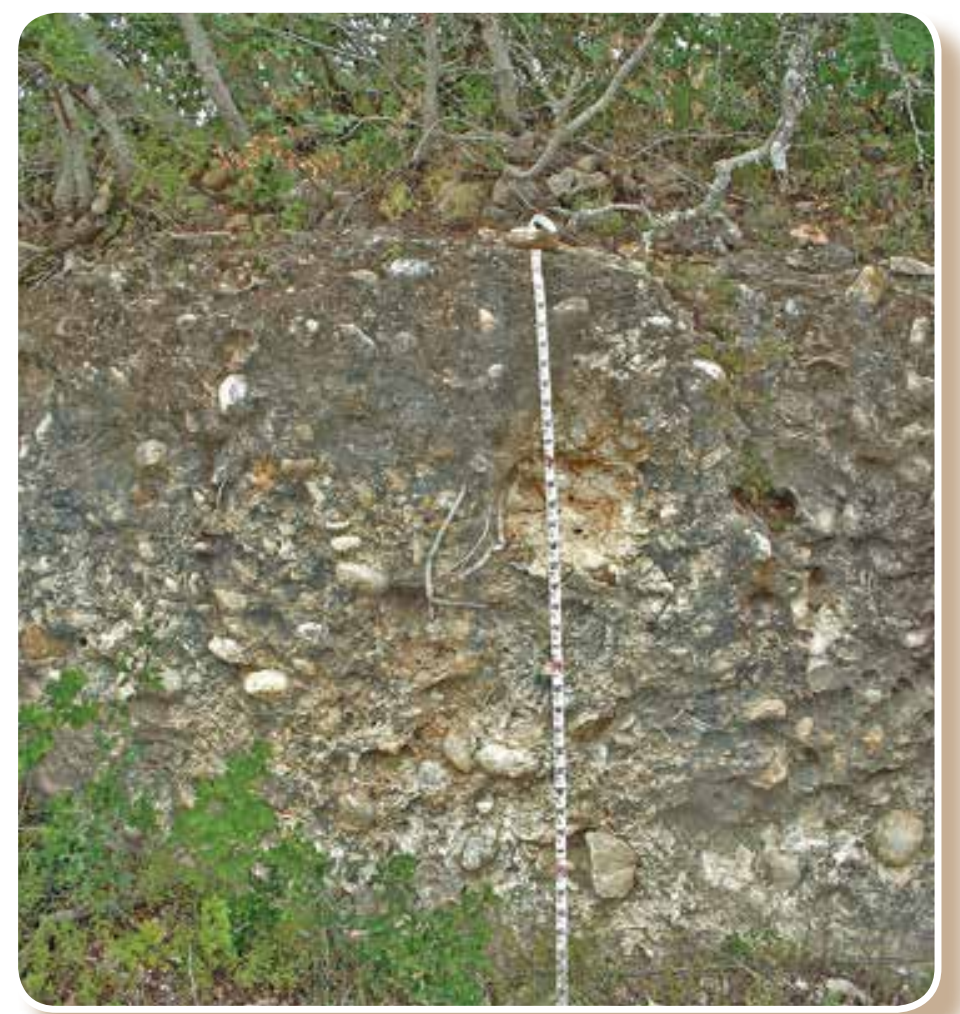

Figure 15. Caliche-cemented Uvalde Gravel located approximately 5.3 miles southeast of the town of D'Hanis in Medina County, Texas. Photograph taken April 13, 2012. 
According to Hill and Vaughn (1898), the Leona Formation (figs. 4-5) is formed by the gravels forming the first terrace of the Nueces and Leona Rivers, below the level of the Uvalde Gravel, and also for the flood-plain deposit extending westward from the city of Uvalde on the Leona River to the Nueces River. Hill and Vaughn (1898) extended the name Leona Formation to include the terrace deposits along all the principal streams of Texas (Sellards and others, 1932). Welder and Reeves (1962) included "a smaller terrace, some 10 to 20 $\mathrm{ft}$ below the Leona terrace level" and the younger alluvium. According to Sellards and others (1932), the Leona Formation is Pleistocene in age. Welder and Reeves (1962) reported a maximum thickness for the Leona Formation of $35 \mathrm{ft}$. Sellards and others (1932) reported that the Leona Formation is composed of red and reddish gray silt and fine gravel with a thickness of 0 to $120 \mathrm{ft}$.

\section{Structure}

The principal structural feature in Uvalde and Medina Counties is the Balcones Fault Zone (fig. 2), which is the result of Miocene age faulting (Weeks, 1945). As is typical elsewhere in the Balcones Fault Zone, most of the faults in the study area are of high-angle, en echelon, normal faults, that are vertical or nearly vertical and downthrown to the southeast (George, 1952). Although most of the faults in Uvalde County are similar to those in Medina County (Holt, 1959) and Bexar County (Arnow, 1959), individual fault displacements typically are less in Uvalde County, where the maximum displacement across the entire Balcones Fault Zone is approximately $700 \mathrm{ft}$ (Welder and Reeves, 1962). The Balcones Fault Zone in Uvalde County probably contains smaller fault displacements because the igneous rock resulted in more stability and formed an area not as easily affected by faulting. Many of the relatively minor faults, with displacements of $20 \mathrm{ft}$ or less, are difficult to identify in the field. Some faults are actually shatter zones - not the single, sharp breaks implied by individual lines on maps.

The structurally complex area of the Balcones Fault Zone contains relay ramps (fig. 16) (Hovorka and others, 1996). Several reports go into a more detailed description of relay ramps and relay ramp development; these include but are not limited to: Clark and Journey (2006), Ferrill and others (2003), Hovorka and others (1998), and Collins and Hovorka (1997). Relay ramps form in extensional fault systems to allow for deformation changes along the fault block (Clark and Journey, 2006). Ramp structures connect the footwall of a fault segment to the stratigraphically higher segment (hanging wall) of the overlapping fault. As stress (extension) occurs and strain along the ramp increases, rotation and internal fracturing occur along the relay ramp (Trudgill, 2002). Subsequently, continuing extension produces cross faults within the relay ramp structure. In Medina County, the faulting of the Balcones Fault Zone has produced a relay-ramp structure that dips to the southwest from the Edwards aquifer recharge zone and extends westward and below land surface from Seco Creek

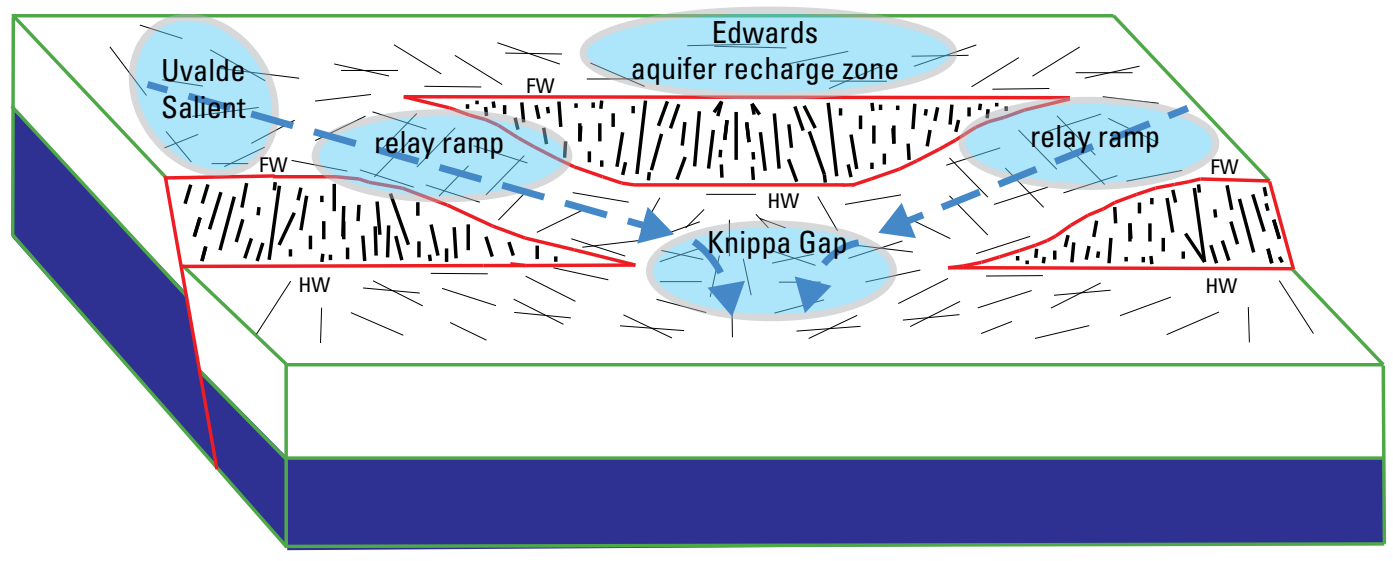

Modified from Clark and Journey, 2006, fig. 5

\section{EXPLANATION}

Inferred structural feature

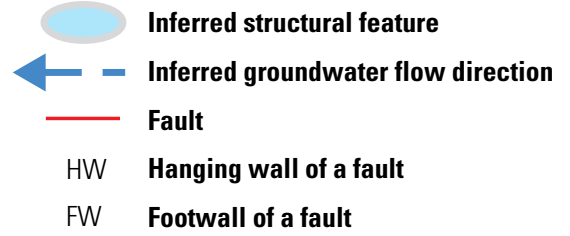

Figure 16. Idealized view of the relay-ramp structure that dips to the northeast from the Uvalde Salient in Uvalde County, the relayramp structure that dips to the southwest from Medina County, and the inferred direction of groundwater flow paths towards the Knippa Gap structural low (trough). 
(Clark and Journey, 2006). In Uvalde County, beds dip from the Uvalde Salient towards the northeast. These two opposing structural dips result in a subsurface structural low (trough) in the area known as the Knippa Gap located near the towns of Knippa and Sabinal, Uvalde County (fig. 1).

\section{Hydrogeologic Cross-Section A-A'}

Hydrogeologic cross-section A-A' (pl. 1, part D), developed for this study, is located in the southern part of the study area extending from the southwest near well YP-69-51606 to the northeast near well TD-69-38-905b. The location and trend of this hydrogeologic cross section was selected to cross the area defined as the Knippa Gap by Maclay and Land (1988). The hydrogeologic cross section shows a distinct structural low (trough) near the center of the hydrogeologic cross section with opposing downfaulting on either side of the trough.

The land-surface altitude along the hydrogeologic cross section ranges from approximately 850 to $960 \mathrm{ft}$. The altitude of the top of the Edwards aquifer ranges from approximately 525 to $-150 \mathrm{ft}$ at wells TD-69-38-905a and YP-69-44-902. The average thickness (appendix 1) of the Edwards aquifer $(590 \mathrm{ft}$ ).is depicted on the geologic cross section. Fault locations were determined from field mapping coupled with well data. Dips of the fault blocks along the section were assumed to be zero unless either well control or surface geology indicated otherwise. Some dips were determined by having multiple wells within the fault blocks. Dips of some fault blocks were determined based on dips observed at the surface outcrops. Cross-section A- $\mathrm{A}^{\prime}$ shows fault parts for six fault blocks, stratigraphic and structural relations of the Edwards aquifer in the subsurface, the location of nine wells, apparent dips, and the interpreted range in altitude of the top and bottom of the Edwards aquifer in the subsurface. The hydrogeologic cross section runs roughly parallel to the Balcones Fault Zone. Fault block 19 is assumed to be horizontal based on data from one well and surface geology. Fault block 19a is a horst (upthrown geologic structure) with no dip relative to fault blocks 19 and 16. Fault block 16 has an apparent dip angle trending towards the east based on the data from the two wells. Fault block 16a is a horst that has resulted in the Edwards aquifer being juxtaposed against the upper confining unit of fault blocks 15 and 16. The dip of fault block 16a is assumed to be zero because of lack of well and surface control. The western part of fault block 15 dips toward the east. There is essentially no dip between well YP-69-44-902 and well YP-69-45-701a. The central part of fault block 15 dips towards the west based on data from wells YP-69-45701a and YP-69-45-5xx. Fault block 15 appears to indicate a structural low (trough) in an area defined by Maclay and Land (1988) as the Knippa Gap. Fault block 14 is up relative to fault block 15 and down relative to fault block 20 with no dip based on surface mapping and data from one well. Fault block 20 dips to the west based on data from two wells coupled with data from the surface mapping.

\section{Hydrogeologic Cross-Section B-B'}

Hydrogeologic cross-section B-B' (pl. 1, part E) is located near the center of the study area and extends from the north from near well YP-69-36-602, through the town of Sabinal, Tex., and terminates near well YP-69-53-2xx in the south. The location and trend of this hydrogeologic cross section were chosen because it crosses through the area defined by Maclay and Land (1988) as the Knippa Gap. The land-surface altitude along the hydrogeologic cross section ranges from about 1,100 to $850 \mathrm{ft}$ above NAVD 88 . The altitude of the top of the Edwards aquifer in cross-section B-B' ranges from 925 to $-325 \mathrm{ft}$ at wells YP-69-36-602 and YP-69-45-8xx. The average thickness (appendix 1) of the Edwards aquifer $(590 \mathrm{ft}$ ) is depicted on the geologic cross section. Hydrogeologic cross-section B-B' shows faults controlling parts of 18 fault blocks, stratigraphic and structural relations of the Edwards aquifer in the subsurface, the location of seven wells, apparent dips, and the variability of interpreted range in altitude of the top and bottom of the Edwards aquifer in the subsurface. Fault locations were determined from field mapping coupled with well data. Dips of the fault blocks are assumed to be zero because of lack of sufficient geologic control. Faults are primarily downthrown to the south along this hydrogeologic cross section in typical en echelon fashion. The hydrogeologic cross section runs perpendicular to the structural low (trough) identified by this study, and through the area defined by Maclay and Land (1988) as the Knippa Gap. Fault blocks 1 and 2 are in the Del Rio Clay outcrop. Fault block 3 and 4 are in the outcrop of the Austin Group. Fault blocks 5 and 6 are downthrown to the south. Fault blocks 7-10 form a horst (geologic feature) identified based on surface mapping, consequently, the Edwards aquifer is uplifted and juxtaposed against the upper confining units. Fault blocks 11-17 continue the en-echelon downthrown pattern to the south. Fault block 18 is upthrown, juxtaposing a part of the Edwards aquifer against the upper confining unit.

\section{Hydrogeologic Characteristics}

The Leona aquifer of the Leona Formation supplies water to wells in several parts of Uvalde and Medina Counties, primarily for domestic and livestock use (figs. 4-5) (Welder and Reeves, 1962). Based on field observations, the Leona aquifer contains fabric selective interparticle porosity with the thickest sections located near the center of valleys and forming the most productive parts of the aquifer (Welder and Reeves, 1962). The gravels forming the Leona aquifer generally are considered unconsolidated. Clay overlies much of the gravels in the Leona aquifer and confines the groundwater resource in many places; therefore, the interaction between groundwater and surface water is often restricted (Welder and Reeves, 1962) and, according to Holt (1959), where the Leona aquifer outcrops, the aquifer is recharged by precipitation, streamflow, and flow from springs flowing from other aquifers. 
The authors noted during field reconnaissance that the Uvalde Gravel (figs. 4-5) has fabric selective interparticle porosity. Caliche generally forms the cement binding the gravels together. Precipitation occurring on the outcrop infiltrates rapidly through these gravels into underlying formations or moves downgradient into the Leona aquifer in stream valleys. Therefore, in the higher topographic areas between the streambeds, the gravel unit is believed to be nonwater-bearing (Welder and Reeves, 1962).

Field reconnaissance showed that the Indio Formation (figs. 4-5) contains fabric selective interparticle porosity in the sands. The sands are generally poorly cemented with carbonate cement (Welder and Reeves, 1962). According to Welder and Reeves (1962), the Indio Formation yields small quantities of water mainly for domestic and livestock uses and the quality of water produced from the formation varies greatly spatially, and in many areas, the formation yields only saline water containing greater than 1,000 milligrams per liter of dissolved solids.

According to Barker and Ardis (1996, p. B53), the upper confining unit to the Edwards aquifer is formed by the Del Rio Clay, Buda Limestone, Eagle Ford Group, Austin Group, Anacacho Limestone, and Escondido Formation (figs. 4-5), and "yield little or no water or a very small amount of water to mostly shallow dug wells." These units form a regional barrier to vertical groundwater flow; however, several formations within this regional barrier have very good localized hydraulic connection with the deeper Edwards aquifer. Springs flow from the Buda Limestone and Austin Group in or near the study area that appear to discharge water from the Edwards aquifer (Clark and Small, 1997; Green and others, 2006). This groundwater moves vertically up through and along fractures or faults and discharges into surficial drainages and probably discharges into the Leona aquifer in the subsurface through similar faults and fractures (Green and others, 2006).

According to Welder and Reeves (1962), the Escondido Formation (figs. 4-5) yields small quantities of saline water in Uvalde and Medina Counties. Getzendaner (1931) stated that many of the wells completed in the Escondido Formation were dry. Field observations by the authors showed that the sandstones in the formation contain fabric selective interparticle porosity and secondary nonfabric selective fracture porosity. Clays and shales of the formation contain fabric selective porosity. The sandstones are partially cemented by carbonates. Field mapping indicated the occurrence of asphalt in the outcrop area appears to form a vertical barrier to the downward movement of water, and subsequently, many of the stock ponds in the Escondido Formation seem to be located in areas containing higher concentrations of asphalt.

Getzendaner (1931) reported that many of the wells drilled into the Anacacho Limestone were dry. Holt (1959) stated that the Anacacho Limestone (figs. 4-5) yields water for domestic purposes only. Groundwater flows vertically up through faults and fractures from the Edwards aquifer and discharges from the Anacacho Limestone and into the Leona River (fig. 1, Leona Springs 2) (Clark and Small, 1997). From field observations, it was determined that the porosity in the limestone portions of the Anacacho Limestone is fabric selective moldic porosity and secondary nonfabric selective fracture and bedding plane porosity. Welder and Reeves (1962) stated that the formation must be cased off during drilling because the bentonitic clays in the formation absorb water and swell.

Welder and Reeves (1962) stated that the Austin Group yields small to moderate amounts of water to wells near the outcrop (figs. 4-5). Banta and Clark (2012) state that water in the Austin Group is derived from many sources including direct infiltration of precipitation, infiltration along stream channels, and artesian water from the underlying Edwards aquifer. In addition, Welder and Reeves (1962) stated that several wells completed in the Austin Group near the city of Uvalde produce large quantities of water, and Holt (1959) reported several wells completed in the Austin Group produced moderate amounts of water. Getzendaner (1931) stated that many of the wells drilled into the Austin Group were dry. Field observations by the authors indicated that porosity in the Austin Group is both fabric selective and nonfabric selective. The fabric selective porosity is mainly in the form of moldic and interparticle porosity. The observed nonfabric selective porosity is in the form of fractures, bedding plane openings, channels (fig. 17), and caves (fig. 18). According to Poston and Chen (1991), the permeability of the Austin Group is 0.01 to 0.001 millidarcy in the rock and 10 to 100 times greater in the fractures.

Leona Springs 1 (figs. 1 and 17) and Leona Springs 2 (fig. 1) in the outcrop of the Austin Group, discharge groundwater, which flows upward from the underlying Edwards aquifer through faults and fractures (Clark and Small, 1997). Green and others (2006) state that the supply of water to many of the springs in the vicinity of the study area are also from water moving up through faults and fractures from the underlying Edwards aquifer under artesian conditions and discharging from the Austin Group. These springs are similar to springs discharging from the Austin Group in Bexar County. Banta and Clark (2012) also state that artesian water moves through faults, fractures, or conduits from the underlying Edwards aquifer, and that the volume of discharge from the Austin Group is often related to the proximity to the fault, fracture, or conduit supplying the water. Banta and Clark (2012) based the conclusions that the volume of discharge increases near faults on changes in water levels and pump tests in wells near faults when compared to ones more distant from faults. Discharge from these springs provides flow to river systems, such as the Leona River, or into the gravels of the Leona Formation (Green and others, 2006).

The Eagle Ford Group yields small quantities of saline water (figs. 4-5) (Welder and Reeves, 1962). Field observations for this study indicated that the Eagle Ford Group contained both fabric selective interparticle porosity and nonfabric selective fracture porosity. 


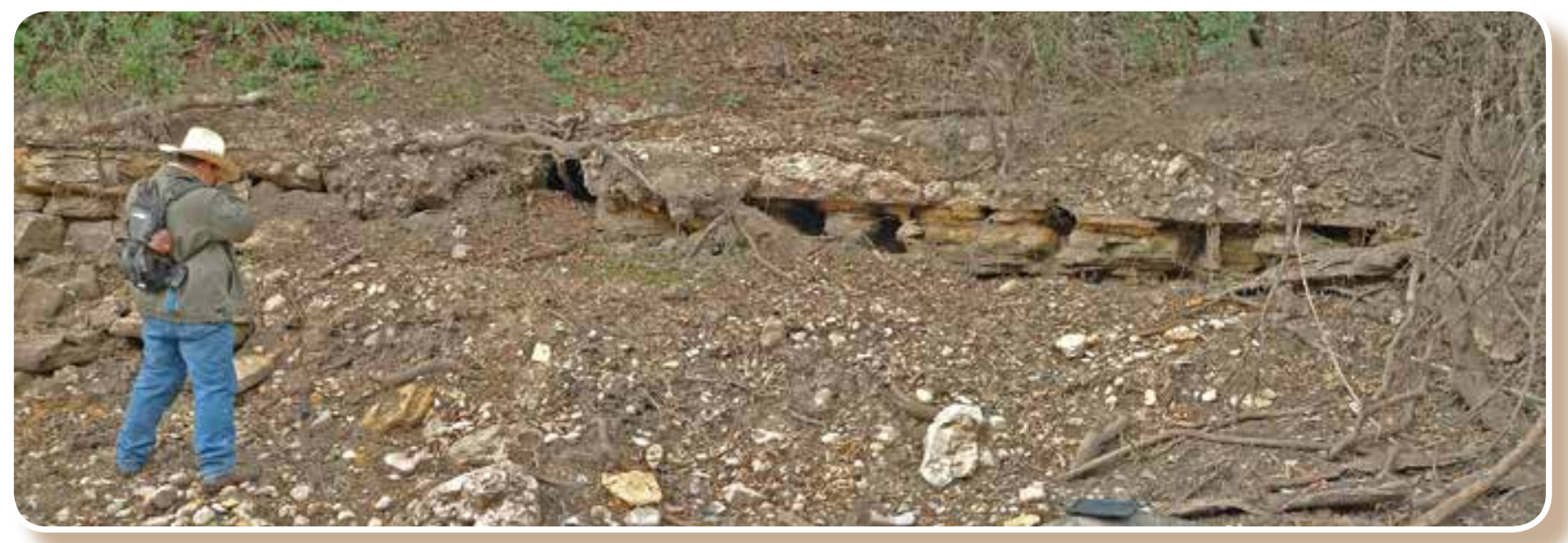

Figure 17. Channel porosity developed along a bedding plane in the Austin Group located near the intermittent Leona Springs 2 on the Leona River in Uvalde County, Texas. Photograph taken January 12, 2012.

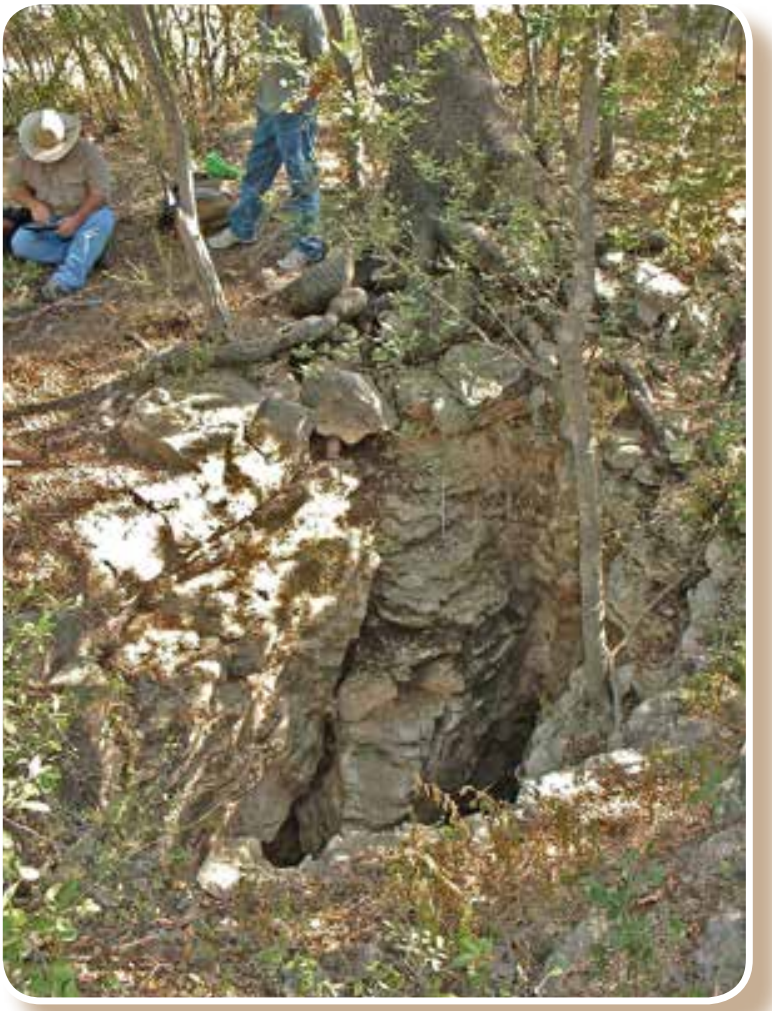

Figure 18. Cave in fractured Austin Group rock located approximately 9.3 miles northeast of city of Uvalde in Uvalde County, Texas. Photograph taken August 7, 2012. 
According to Welder and Reeves (1962), near the city of Uvalde, the Buda Limestone supplies moderate quantities of water for domestic and irrigation uses (figs. 4-5). Porosity in the Buda Limestone appears to be related to nonfabric selective fractures. Getzendaner (1931) stated that water produced from the Buda Limestone is related to the close proximity of faults. Several springs issue from the Buda Limestone near the study area, and the source of the water is believed to originate from the underlying Edwards aquifer (Green and others, 2006). Water in the Edwards aquifer flows upward along and through faults and fractures under artesian conditions and discharges from the Buda Limestone (Green and others, 2006).

Welder and Reeves (1962) reported that the formation currently (2013) referred to as the Del Rio Clay is not known to yield water in Uvalde County (figs. 4-5). The Del Rio Clay contains little porosity based on its lithology. The authors noted during field observations that in surface outcrop the formation is often used by ranchers for developing stock ponds.

The Edwards aquifer is a major aquifer in south-central Texas (figs. 4-5) (George and others, 2011). In the study area, the Edwards aquifer is composed of the Devils River Formation in the Devils River Trend and the West Nueces Formation, upper McKnight Formation, and Salmon Peak Formation in the Maverick Basin (figs. 4-5) (Clark and Small, 1997). According to Maclay and Small (1976), the Edwards aquifer has relatively large porosity and permeability, in part, from the development and redistribution of secondary porosity.

Effective porosity in the Edwards aquifer outcrop is a result of both fabric and nonfabric selective porosity (Small and Clark, 2000). Maclay and Small (1976) state that the effective porosity in the Edwards aquifer is closely associated with large permeability such as is common with karst features. Porosity-test data reported by Small and Maclay (1982), determined by mercury injection, indicate that the Edwards aquifer contains porosities ranging from 5 to 35 percent. For a detailed description of the geology and hydrogeology of the Edwards aquifer refer to Maclay and Small $(1976,1984)$ and Small and Maclay (1982).

The Edwards aquifer in the Devils River Trend is formed in the Devils River Formation and is one of the most porous and permeable units in the study area (fig. 4) (Clark and Small, 1997). The permeable zones generally are associated with solutionally enlarged bedding planes and fractures. Although most of the permeability probably results from fractures, the aquifer also contains nonfabric selective bedding plane, fracture, breccia, vug, channel, and cave porosity; in addition, the aquifer contains fabric selective, intercrystalline, burrow, and moldic porosity (Clark, 2003). The vertical fractures near the top of the Edwards aquifer in the Devils River Formation provide the most effective paths for recharge, and where subaerially exposed, these fractures greatly increase the rate of recharge per a given precipitation event (Welder and Reeves, 1962).
The upper part of the Edwards aquifer in the Devils River Formation contains fabric selective moldic, and nonfabric selective bedding plane, fracture, vug, channel, and cave porosity (fig. 4) (Maclay and Land, 1988; Clark, 2003). The middle part of the Edwards aquifer in the Devils River Formation contains nonfabric selective, interconnected vug porosity making the middle section of the unit permeable; although probably less so than the upper part of the unit (Clark, 2003). The lower part of the Edwards aquifer in the Devils River Formation contains both fabric selective burrows and intercrystalline porosity and nonfabric selective porosity in the forms of vugs and fractures.

The Edwards aquifer of the Maverick Basin facies is formed in the Salmon Peak Formation, upper unit of the McKnight Formation, and basal nodular unit of the West Nueces Formation (fig. 5) (Clark and Small, 1997). The permeability of the Edwards aquifer in the Salmon Peak Formation (fig. 5) decreases stratigraphically with depth. The porosity appears to be the result of nonfabric selective porosity in the form of solutionally enlarged fractures, bedding planes, and some cavern development (Clark, 2003). The lowermost $250 \mathrm{ft}$ of this unit has relatively minor nonfabric selective vug porosity (less than 3 percent) and nonfabric selective fracture porosity with little permeability (Small and Maclay, 1982).

The upper unit of the McKnight Formation in the Edwards aquifer contains some fabric selective moldic porosity that evolved from the removal of evaporites and subsequent breccia resulting from the collapse of weakened bedding. The upper unit of the McKnight Formation also contains nonfabric selective fracture and porosity (Clark and Small, 1997).

Only the basal nodular unit of the West Nueces Formation is present in the study area (fig. 5). The basal nodular unit of the West Nueces Formation contains nonfabric selective fractures with a small amount of porosity (less than 3 percent) (Sieh, 1975).

The Trinity aquifer is considered a major aquifer by the Texas Water Development Board (figs. 4-5) (George and others, 2011). The Trinity aquifer is recharged by lateral subsurface flow from the Edwards Plateau, infiltration of precipitation, and seepage of surface water (Barker and Ardis, 1996). Although the Trinity aquifer is a major aquifer in south-central Texas, it is considered a lower confining unit to the Edwards aquifer because the Trinity aquifer is less permeable than the Edwards aquifer, and the potential of the Trinity aquifer to provide and transmit water is appreciably less than that of the Edwards aquifer (Barker and Ardis, 1996). Ashworth (1983) subdivided the Trinity aquifer into the upper, middle, and lower aquifers. The upper Trinity aquifer underlies the Edwards aquifer. According to Ashworth (1983), few wells are completed in the upper Trinity aquifer because it generally produces small quantities of poor quality water. In south-central Texas, the upper Trinity aquifer is formed in the upper member of the Glen Rose Limestone (Ashworth, 1983). According to Ashworth (1983), the upper Trinity aquifer is separated from the middle Trinity aquifer by thin, 
hydraulically tight interbeds. Porosity in the upper Trinity aquifer is primarily in the form of nonfabric selective fractures and caves that formed along solutionally enlarged fractures (Clark, 2004). It also contains fabric selective boxwork, breccia, and moldic porosity in certain intervals associated with variations in lithology (Clark, 2004).

Getzendaner (1931, p. 104) reported that "Many small wells get their water from the serpentines." According to Welder and Reeves (1962), many of the wells in Uvalde County penetrate basalt and serpentine (not shown on figs. 4 or 5) and further reported that wells containing several hundred feet of serpentine were unproductive; however, in wells that have several tens of feet of serpentine but open to other aquifers, production was unaffected. A few wells produce a small amount of water from basalt (Welder and Reeves, 1962). The "igneous swarm" in Uvalde and Medina Counties probably reduced the transmissivity of the Edwards aquifer on a regional scale (Smith and others, 2002) and influence of groundwater flow and quality (Blome and others, 2004). The porosity and permeability of these intrusive rocks are decreased by secondary minerals deposited within the primary porosity (Blome and others, 2004). Volcanic plugs, dikes, and sills are the most common form of the igneous masses (Welder and Reeves, 1962). These features result from the intrusion and emplacement of molten material; therefore, the porosity in the basalts is from nonfabric selective fractures and is related to cooling and contraction of the magma bodies (figs. 14-15) (Clark, 2003).

Groundwater flow paths in the Edwards aquifer are influenced by faulting and geologic structure (fig. 16). Faulting associated with the Balcones Fault Zone affect groundwater flow paths by (1) forming a barrier to flow which results in water moving parallel to the fault plane (Maclay, 1995), (2) increasing flow across the fault plane because of fracturing and juxtaposing porous and permeable units, or (3) no effect on the groundwater flow paths. Maclay (1995) stated that (based on Small,1986) faults could be barriers to groundwater flow paths where the aquifer is offset by 50 percent or more and result in flow moving parallel to the fault. According to Clark and Journey (2006, p. 2), "the amount of displacement along a particular fault tends to vary, and thus the effectiveness of a fault as a barrier to flow probably changes along the fault plane. Near a fault tip [where a fault ends no barrier to flow exists; as displacement down the fault plane increases, the effectiveness of the fault as a barrier to flow increases." The structural high, known as the Uvalde Salient, results in groundwater moving off of the high and downgradient (dip) towards a structural low (trough) to the east (pl. 1, fig. 16). Groundwater moving down the relay ramp in northern Medina County flows downgradient (dip) to the structural low (trough) from the northeast to the southwest (pl. 1, fig. 16) (Clark and Journey, 2006). Clark and Journey (2006) reported up to four separate fault bounded flow paths moving down the northern Medina relay ramp towards the southwest. The two opposing flow paths join within the structural low (trough) and turn south flowing through the area known as the Knippa Gap
(Maclay and Land, 1988). According to Maclay (1995), south of the towns of Knippa and Sabinal is an area of minimal fault displacement (plate 1, parts $\mathrm{A}$ and $\mathrm{D}$ ) that was designated by Maclay and Land (1988) as the Knippa Gap.

\section{Summary}

The Edwards aquifer is the primary source of potable water for the San Antonio area in south-central Texas. To better understand the function of the area known as the Knippa Gap as it pertains to its geology and structure, the geologic framework, structure, and hydrogeologic characteristics of the area were evaluated by the U.S. Geological Survey (USGS) in cooperation with the U.S. Army Corps of Engineers (USACE) - Fort Worth District. The purpose of this report is to describe the geologic framework, structure, and hydrogeologic characteristics of the Knippa Gap area of the Devils River Trend and Maverick Basin in eastern Uvalde and western Medina Counties, Texas. The Knippa Gap was postulated to channel or restrict flow in the Edwards aquifer in eastern Uvalde County; its existence was based on a series of numerical simulations of groundwater flow in the aquifer.

The rocks within the study area are sedimentary and igneous and range in age from the Lower Cretaceous to the Pleistocene. The sedimentary rocks are limestone, chalk, gravel, sand, silt, and clay. The igneous rocks are ultramafic to intermediate in composition.

By using all of the data that were compiled and collected for this study, a map was constructed depicting the geologic framework, structure, and hydrogeologic characteristics of the Knippa Gap area in eastern Uvalde and western Medina Counties, Tex. The map also shows the interpreted structural dip directions and interpreted location of a structural low (trough) in the area known as the Knippa Gap.

The geologic framework of the study area is composed of sedimentary rocks forming the Devils River Trend and the Maverick Basin. The Lower Cretaceous Devils River Trend is formed in the Devils River Formation. The Lower Cretaceous Maverick Basin rocks are formed in the West Nueces Formation, McKnight Formation, and Salmon Peak Formation. Overlying rocks of both depositional provinces are the Upper Cretaceous Del Rio Clay, Buda Limestone, Eagle Ford Group, Austin Group, Anacacho Limestone, Escondido Formation, the Eocene Indio Formation, the Pliocene Uvalde Gravel, and the Pleistocene Leona Formation.

Episodes of Upper Cretaceous magmatic activity resulted in the emplacement of numerous and widely scattered igneous bodies from intrusive and extrusive events. The igneous bodies are located in all of the formations in the study area.

The principal structural feature in Uvalde and Medina Counties is the Balcones Fault Zone, which is the result of Miocene age faulting. The structurally complex area of the Balcones Fault Zone contains relay ramps that form in extensional fault systems to allow for deformation changes along the fault block. In Medina County, the faulting of the 
Balcones Fault Zone has produced a relay-ramp structure that dips to the southwest from the Edwards aquifer recharge zone and extends westward. In Uvalde County, beds dip from the Uvalde Salient towards the northeast. These two opposing structural dips result in a subsurface structural low (trough) feature in the area known as the Knippa Gap, which is located near the towns of Knippa and Sabinal in Uvalde County.

Hydrogeologic cross-section A-A', developed for this study, is located in the southern part of the study area extending from the southwest near well YP-69-51-606 to the northeast near well TD-69-38-905b. The location and trend of this hydrogeologic cross section was selected to cross the area defined as the Knippa Gap by previous investigators. The geologic cross section shows a distinct structural low (trough) near the center of the hydrogeologic cross section with opposing downfaulting on either side of the trough.

Hydrogeologic cross-section B- $\mathrm{B}^{\prime}$ is located near the center of the study area, and extends from the north to the south, through the town of Sabinal, Tex. The location and trend of this hydrogeologic cross section was chosen because it crosses through the area defined as the Knippa Gap.

The Leona aquifer supplies water to wells in several parts of the Uvalde and Medina Counties primarily for domestic and livestock uses. The Uvalde Gravel is not known to yield water in the study area. The Indio Formation yields small quantities of water mainly for domestic and livestock uses.

The upper confining unit to the Edwards aquifer is formed by the Del Rio Clay, Buda Limestone, Eagle Ford Group, Austin Group, Anacacho Limestone, and Escondido Formation. These units form a regional barrier to vertical groundwater flow; however, several formations within this regional barrier have very good localized hydraulic connection with the deeper Edwards aquifer.

The Edwards aquifer is a major aquifer in south-central Texas. In the study area, the Edwards aquifer is composed of the Devils River Formation in the Devils River Trend, and the West Nueces Formation, and upper McKnight Formation, and Salmon Peak Formation in the Maverick Basin. The Edwards aquifer has relatively large porosity and permeability, in part from the development and redistribution of secondary porosity.

Groundwater flow paths in the Edwards aquifer are influenced by faulting and geologic structure. Faults could be barriers to groundwater flow paths where the aquifer is offset by 50 percent or more and result in flow moving parallel to the fault. The effectiveness of a fault as a barrier to flow probably changes along the fault plane as the amount of displacement changes. The structural high, known as the Uvalde Salient, results in groundwater moving off of the high and downgradient (dip) towards a structural low (trough) to the east. Groundwater moving down the relay ramp in northern Medina County flows downgradient (dip) to the structural low (trough) from the northeast to the southwest bounded by large displacement. The two opposing flow paths join within the structural low (trough) and turn south flowing through the area known as the Knippa Gap.

\section{References Cited}

Abbot, P.L., and Woodruff, C.M., 1986, The Balcones Escarpment-Preface, Accessed May 22, 2013, at http:// www.lib.utexas.edu/geo/balcones_escarpment/preface.html.

Adkins, W.C., 1932, The Mesozoic system in Texas, in Sellards, E.H., Adkins, W.C., and Plummer, F.B., eds., The geology of Texas: University of Texas, Publication 3252, p. 329-518.

Arnow, Ted, 1959, Ground-water geology of Bexar County, Texas: Texas Board of Water Engineers Bulletin 5911, 62 p.

Ashworth, J.B., 1983, Ground-water availability of the Lower Cretaceous formations in the Hill Country of south-central Texas: Texas Department of Water Resources Report 273, $173 \mathrm{p}$.

Banta, J.R., and Clark, A.K., 2012, Groundwater levels and water-quality observations pertaining to the Austin Group, Bexar County, Texas, 2009-11: U.S. Geological Survey Scientific Investigations Report 2012-5278, 18 p., 2 apps.

Barker, R.A., and Ardis, A.F., 1996, Hydrogeologic framework of the Edwards-Trinity aquifer system, west-central Texas: U.S. Geological Survey Professional Paper 1421-B, 61 p.

Barnes, V.E., 1974, Geologic atlas of Texas, San Antonio sheet: Austin, University of Texas, Bureau of Economic Geology, scale 1:250,000.

Barnes, V.E., 1977, Geologic atlas of Texas, Del Rio sheet: Austin, University of Texas, Bureau of Economic Geology, scale $1: 250,000$.

Bates, R.L., and Jackson, J.A., 1987, Glossary of geology (3d ed.): American Geological Institute, 232 p.

Blome, C.D., Faith, J.R., Pedraza, D.E., Ozuna, G.B., Cole, J.C., Clark, A.K., Small, T.A., Morris, R.R., 2005, Geologic map of the Edwards aquifer recharge zone, south-central Texas: U.S. Geological Survey Scientific Investigations Map 2873.

Blome, C.D., Miggins, D.P., and Smith, D.V., 2004, Geophysical and isotopic investigations of the Uvalde intrusive field, south-central Texas: Gulf Coast Association of Geological Societies Transactions, v. 54, p. 61.

Choquette, P.W., and Pray, L.C., 1970, Geologic nomenclature and classification of porosity in sedimentary carbonates: American Association of Petroleum Geologists Bulletin, v. 54 , no. 2 , p. $207-250$.

Clark, A.K., 2003, Geologic framework and hydrologic characteristics of the Edwards aquifer, Uvalde County, Texas: U.S. Geological Survey Water-Resources Investigations Report 03-4010, 17 p., 1 pl. 
Clark, A.K., 2004, Geologic framework and hydrologic characteristics of the Glen Rose Limestone, Camp Stanley Storage Activity, Bexar County, Texas: U.S. Geological Scientific Investigations Map 04-2831, 1 pl.

Clark, A.K., and Journey, C.A., 2006, Flow paths in the Edwards aquifer, northern Medina and northeastern Uvalde Counties, Texas, based on hydrologic identification and geochemical characterization and simulation: U.S. Geological Survey Scientific Investigations Report 20065200,48 p.

Clark, A.K., and Small, T.A., 1997, Geologic framework of the Edwards aquifer and upper confining unit, and hydrogeologic characteristics of the Edwards aquifer, southcentral Uvalde County, Texas: U.S. Geological Survey Water-Resources Investigations Report 97-4094, 16 p., 1 pl.

Collins, E.W., 2000, Geologic map of the New Braunfels, Texas, 30×60 minute quadrangle - Geologic framework of an urban-growth corridor along the Edwards aquifer, southcentral Texas: Bureau of Economic Geology, Miscellaneous Map No. 39, 1:250,000-scale map, with text, p. 1-28.

Collins, E.W., and Hovorka, S.D., 1997, Structure map of the San Antonio segment of the Edwards aquifer and Balcones Fault Zone, south-central Texas: Structural framework of a major limestone aquifer: Kinney, Uvalde, Medina, Bexar, Comal, and Hays Counties: The University of Texas at Austin, Bureau of Economic Geology, Miscellaneous Map No. 38, scale 1:250,000, 2 sheets.

Dittmar, F.W., Deike, M.L., and Richmond, D.L., 1977, Soil survey of Medina County, Texas: U.S. Department of Agriculture-Soil Conservation Service, 92 p. plus maps, accessed on July 18, 2013, at http://soildatamart.nrcs.usda. gov/Manuscripts/TX325/0/Medina.pdf.

Dumble, E.T., 1892, Notes on the geology of the valley of the middle Rio Grande: Geological Society of America Bulletin, v. 3, p. 219-230.

Dunham, R.J., 1962, Classification of carbonate rocks according to depositional texture, in Classification of Carbonate Rocks Symposium: American Association of Petroleum Geologists Memoir 1, p. 108-121.

Edwards Aquifer Authority, 2013, History of the aquifer, accessed June 2013, at http://www.edwardsaquifer.org/ index.php/aquifer_education/discover_the_edwards_ aquifer/about_the_aquifer/history_of_the_aquifer/.

Environmental Systems Research Institute, Inc., 2013, Geodatabases accessed on May 22, 2013, at http://resources. arcgis.com/content/geodatabases/10.0/about.

Ewing, T.E., 1991, The tectonic framework of Texas with accompanying tectonic map of Texas: Austin, University of Texas, Bureau of Economic Geology, 36 p.
Ewing, T.E., 2011, Southwest Texas heavy oil province-A review: Search and Discovery Article \#80133, accessed September 11, 2012, at http://www.searchanddiscovery. com/documents/2011/80133ewing/ndx_ewing.pdf.

Ewing, T.E., and Barker, D.S., 1986, Upper Cretaceous igneous rocks of the Uvalde area, southwest Texas: San Antonio, South Texas Geological Society Guidebook, p. 1-5.

Federal Geographic Data Committee, 2012, Geospatial metadata standards: Federal Geographic Data Committee, accessed January 2013, at http://www.fgdc.gov/index.html.

Fenneman, N.M., 1931, Physiography of the Western United States: New York, McGraw-Hill Book Company, Inc., 510 p., 1 pl.

Fenneman, N.M., and Johnson, D.W., 1946, Physical divisions of the United States: U.S. Geological Survey, scale 1:7,000,000, 1 sheet.

Ferrill, D.A., Sims, D.W., Morris, A.P., Waiting, D.J., and Franklin, N., 2003, Structural controls on the Edwards aquifer/Trinity aquifer interface in the Camp Bullis quadrangle, Texas: Prepared for Edwards Aquifer Authority and U.S. Army Corps of Engineers, accessed on June 5, 2013, at http://data.edwardsaquifer.org/files/SWRI_Camp_ Bull_Rpt.pdf.

Freeman, V.L., 1961, Contact of Boquillas flags and Austin Chalk in Val Verde and Terrell Counties, Texas: Bulletin of American Association of Petroleum Geologists, v. 45, p. 105-107.

George, P.G., Mace, R.E., and Petrossian, Rima, 2011, Aquifers of Texas: Texas Water Development Board Report $380,172 \mathrm{p}$.

George, W.O., 1952, Geology and ground-water resources of Comal County, Texas: U.S. Geological Survey WaterSupply Paper 1138, $126 \mathrm{p}$.

Getzendaner, F.M., 1931, Mineral resources of Texas, Uvalde County: Austin, University of Texas, Bureau of Economic Geology Mineral Resources Pamphlet, p. 93-111.

Green, R.T., Bertetti, F.P., Franklin, N.M., Morris, A.P., Ferrill, D.A., and Klar, R.V., 2006, Evaluation of the Edwards aquifer in Kinney and Uvalde Counties, Texas: San Antonio, Texas, Southwest Research Institute, 45 p. plus appendixes.

Greenwood, Robert, 1956, Submarine volcanic mudflow and limestone dikes in the Grayson Formation (Cretaceous) of central Texas: Gulf Coast Association Geological Society Transactions, v. 6, p. 167-177.

Hazzard, R.T., 1956, Cretaceous rocks south of Tarpley to Del Rio and road log for third part of San Angelo Geological Society field trip, March 1956, in San Angelo Geological Society Guidebook, Four Provinces Field Trip, p. 43-73. 
Hill, R.T., 1901, Geography and geology of the Black and Grand Prairies, Texas: U.S. Geological Survey Annual Report 21, pt. 7, 666 p.

Hill, R.T., and Vaughan, T.W., 1898, Geology of the Edwards Plateau and Rio Plain adjacent to Austin and San Antonio, Texas, with reference to the occurrence of underground waters, in Walcott, C.D., Eighteenth annual report of the United States Geological Survey to the Secretary of the Interior, 1896-1897; part II, papers chiefly of a theoretical nature: U.S. Geological Survey, p. 193-321.

Holt, C.L.R., Jr., 1959, Geology and ground-water resources of Medina County, Texas: U.S. Geological Survey WaterSupply Paper 1422, 213 p.

Hovorka, S.D., Dutton, A.R., Ruppel, S.C., and Yeh, J.S., 1996, Edwards aquifer ground-water resources - Geologic controls on porosity development in platform carbonates, south Texas: The University of Texas at Austin, Bureau of Economic Geology Report of Investigations No. 238, 75 p.

Humphreys, C.H., 1984, Stratigraphy of the lower Cretaceous (Albian) Salmon Peak Formation of the Maverick Basin, south Texas, in Stratigraphy and structure of the Maverick Basin and Devils River trend, lower Cretaceous, southwest Texas: San Antonio Geological Society, Field Trip Guidebook, Annual meeting of the AAPG and SEPM, p. 34-59.

Kittenbrink, E.C., Jr., ed., 1983, Structure and stratigraphy of the Val Verde Basin-Devils River Uplift, Texas: West Texas Geological Society Field Trip Guidebook, 148 p.

Kuniansky, E.L., and Holligan, K.Q., 1994, Simulations of flow in the Edwards-Trinity aquifer system and contiguous hydraulically units, west-central Texas: U.S. Geological Survey Water-Resources Investigations Report 93-4093, $40 \mathrm{p}$.

Liddle, R.A., 1918, The geology and mineral resources of Medina County: The University of Texas, Austin, University of Texas Bulletin 1860, 177 p., 9 pls.

Lindgren, R.J., 2006, Diffuse-flow conceptualization and simulation of the Edwards aquifer, San Antonio, Texas: U.S. Geological Survey Scientific Investigations Report 2006-5319, 48 p.

Lindgren, R.J., Dutton, A.R., Hovorka, S.D., Worthington, S.R.H., and Painter, S., 2004, Conceptualization and simulation of the Edwards aquifer, San Antonio region, Texas: U.S. Geological Survey Scientific Investigations Report 2004-5277, 143 p.

Lonsdale, J.T., 1927, Igneous rocks of the Balcones Fault Zone region of Texas: Austin, University of Texas Bulletin 2744, $178 \mathrm{p}$.
Lozo, F.E., Jr., and Smith, C.I., 1964, Revision of Comanche Cretaceous stratigraphic nomenclature, southern Edwards Plateau, southwest Texas: Gulf Coast Association of Geological Societies Transactions, v. 14, p. 285-306.

Luttrell, P.E., 1977, Carbonate facies distribution and diagenesis associated with volcanic cones in the Anacacho Limestone (upper Cretaceous), Elaine field, Dimmit (and Zavala) County, Texas: Bureau of Economic Geology Report of Investigations No. 89, 260 p.

Maclay, R.W., 1995, Geology and hydrology of the Edwards aquifer in the San Antonio area, Texas: U.S. Geological Survey Water-Resources Investigations Report 95-4186, $64 \mathrm{p}$.

Maclay, R.W., and Land, L.F., 1988, Simulation of flow in the Edwards aquifer, San Antonio region, Texas, and refinement of storage and flow concepts: U.S. Geological Survey Water-Supply Paper, 2336-A, 48 p.

Maclay, R.W., and Small, T.A., 1976, Progress report on geology of the Edwards aquifer, San Antonio area, Texas, and preliminary interpretation of borehole geophysical and laboratory data on carbonate rocks: U.S. Geological Survey Open-File Report 76-627, 65 p.

Maclay, R.W., and Small, T.A., 1984, Carbonate geology and hydrology of the Edwards aquifer in the San Antonio area, Texas: U.S. Geological Survey Open-File Report 83-537, $72 \mathrm{p}$.

Martin, K.G., 1967, Stratigraphy of the Buda Limestone, south-central Texas: Society of Economic Paleontologists and Mineralogists, Permian Basin Section, Publication 67-8, p. 286-299.

Miggins, D.P., Blome, C.D., and Smith, D.V., 2004, Preliminary 40Ar/39Ar geochronology of igneous intrusions from Uvalde County, Texas-Defining a more precise eruption history for the southern Balcones Volcanic Province: U.S. Geological Survey Open-File Report 2004-1031, 31 p.

Miller, B.C., 1983, Physical stratigraphy and facies analysis, Lower Cretaceous, Maverick Basin and Devils River trend, Uvalde and Real Counties, Texas: Arlington, Tex., University of Texas at Arlington, M.A. thesis, 217 p.

Miller, B.C., 1984, Physical stratigraphy and facies analysis, Lower Cretaceous, Maverick Basin and Devils River trend, Uvalde and Real Counties, Texas, in Smith, C.L., ed., Stratigraphy and structure of the Maverick Basin and Devils River trend, Lower Cretaceous, southwest Texas-A field guide and related papers: South Texas Geological Society, p. 3-33.

Nordstrom, P.L., and Quincy, Roger, 1999, UM-50 ground-water data system data dictionary: Texas Water Development Board, 99 p. 
Pisasale, E.T., 1980, Surface and subsurface depositional systems in the Escondido Formation, Rio Grande Embayment, South Texas: University of Texas at Austin, M.A. thesis, $72 \mathrm{p}$.

Poole, F.G., Perry, W.J., Jr., Madrid, R.J., and AmayaMartinez, R., 2005, Tectonic synthesis of the OuachitaMarathon-Sonora orogenic margin of southern Laurentia: Stratigraphic and structural implications for timing of deformational events and plate-tectonic model: Geological Society of America Special Papers 393, p. 543-596.

Poston, S.W., and Chen, H.Y., 1991, Fitting type curves to Austin Chalk wells: Society of Petroleum Engineers, accessed on June 5, 2012, at http://www.onepetro.org/mslib/ servlet/onepetropreview?id=00021653.

Rose, P.R., 1972, Edwards Group, surface and subsurface, central Texas: University of Texas at Austin, Bureau of Economic Geology Report of Investigations No. 74, 198 p.

Sayre, A.N., 1936, Geology and ground-water resources of Uvalde and Medina Counties, Texas: U.S. Geological Survey Water-Supply Paper 678, 146 p.

Sayre, A.N., 1942, Recharge, movement and discharge in the Edwards Limestone reservoir, Texas: Transactions of American Geophysical Union, pt. 1, p. 19-27.

Sellards, E.H., 1919, The geology and mineral resources of Bexar County: Austin, the University of Texas Bulletin 1932, 197 p.

Sellards, E.H., 1932, Oil fields in igneous rocks in coastal plain of Texas: American Association of Petroleum Geologists Bulletin v. 16, no. 8, p. 741-768.

Sellards, E.H., Adkins, W.S., and Plummer, F.B., 1932, The geology of Texas, v. 1, Stratigraphy: Austin, the University of Texas, Bureau of Economic Geology Bulletin No. 3232, $1007 \mathrm{p}$.

Shumard, B.F., 1860, Observations upon the Cretaceous strata of Texas: Academy of Science of St. Louis Transactions, v. 1, p. 583-590.

Sieh, T.W., 1975, Edwards (Balcones Fault Zone) aquifer test well drilling investigation: Texas Water Development Board, fig. 18.

Singhal, B.B.S., and Gupta, R.P., 1999, Applied hydrogeology of fractured rocks: Dordrecht, Netherlands, Kluwer Academic Publishers, 371 p.

Small, T.A., 1986, Hydrogeologic sections of the Edwards aquifer and its confining units in the San Antonio area, Texas: U.S. Geological Survey Water-Resources Investigations Report 85-4259, 52 p.
Small, T.A., and Clark, A.K., 2000, Geologic framework and hydrogeologic characteristics of the Edwards aquifer outcrop, Medina County, Texas: U.S. Geological Survey Water-Resources Investigations Report 2000-4195, 15 p.

Small, T.A., and Maclay, R.W., 1982, Test-hole data for the Edwards aquifer in the San Antonio area, Texas: Texas Department of Water Resources LP-171, 153 p.

Smith, B.D., Smith, D.V., Hill, P.L., Labson, V.F., 2003, Helicopter electromagnetic and magnetic survey data and maps, Seco Creek area, Medina and Uvalde Counties, Texas: U.S. Geological Survey Open-File Report 2003-226, $51 \mathrm{p}$.

Smith, D.V., McDougal, R.R., Smith, B.D., and Blome, C.D., 2008, Distribution of igneous rocks in Medina and Uvalde Counties, Texas, as inferred from aeromagnetic data: U.S. Geological Survey Scientific Investigations Report 20075191,12 p.

Smith, D.V., Smith, B.D., and Hill, P.L., 2002. Aeromagnetic survey of Medina and Uvalde Counties, Texas: U.S. Geological Survey Open-File Report 02-0049. Available at http://pubs.usgs.gov/of/2002/ofr-02-0049/.

Stein, W.G., and Ozuna, G.B., 1995, Geologic framework and hydrogeologic characteristics of the Edwards aquifer recharge zone, Bexar County, Texas: U.S. Geological Survey Water-Resources Investigations Report 95-4030, 8 p.

Stevens, J.W., and Richmond, D.L., 1970, Soil survey of Uvalde County, Texas: U.S. Department of Agriculture-Soil Conservation Service, 101 p. plus maps, accessed on July 18, 2013, at http://soildatamart.nrcs.usda.gov/Manuscripts/ TX463/0/Uvalde.pdf.

Texas Water Development Board, 2010, Regional and state total population projections 2000-2060 accessed June 14, 2011, at http:/www.twdb.state.tx.us/waterplanning/data/ projections/2012/doc/Population/1StatePopulation.pdf.

Trevino, R.H., 1988, Facies and depositional environments of the Boquillas Formation, upper Cretaceous of southwest Texas: Arlington, Tex., University of Texas at Arlington, M.A. thesis, p. 54-63.

Trowbridge, A.C., 1923, A geologic reconnaissance in the Gulf Coastal Plain of Texas, near the Rio Grande, in Shorter contributions to general geology, 1922: U.S. Geological Survey Professional Paper, 131-D, p. D85-D107.

Trudgill, B.D., 2002, Structural controls on drainage development in the Canyonlands grabens of southeast Utah, USA, in Underhill, J.R., and Trudgill, B.D., eds., The structure and stratigraphy of rift systems: American Association of Petroleum Geologists Bulletin Special Issue, v. 86 , no. 6 , p. 1095-1112. 
Udden, J.A., 1907, Report on a geological survey of the lands belonging to the New York and Texas Land Company Ltd. in the upper Rio Grande Embayment in Texas: Augustana Library Publication 6, p. 51-107.

U.S. Census Bureau, 2012a, Annual estimates of the resident population for incorporated places over 50,000, ranked by July 1, 2011 population: April 1, 2010 to July 1, 2011 (SUB-EST2011-01), accessed January 6, 2013, at http:// www.census.gov/popest/data/cities/totals/2011/index.html.

U.S. Department of Agriculture, Production and Marketing Administration, 1954, Aerial photographs of Medina and Uvalde Counties, Texas: Aerial photography by Aero Exploration Company, Tulsa, Oklahoma.

U.S. Geological Survey, 2013, Geospatial Metadata Validation Service - Formal metadata information and software, accessed on March 27, 2013, at http://geo-nsdi.er.usgs.gov/ validation/.

Vaughan, T.W., 1900a, Uvalde Folio: Washington, D.C., U.S. Geological Survey Folio 64, 7 p., 3 pls.

Vaughan, T.W., 1900b, Reconnaissance in the Rio Grande coal fields of Texas: Washington, D.C., U.S. Geological Survey Bulletin 164, 95 p., 11 pls.
Weeks, A.W., 1945, Balcones, Luling and Mexia fault zones in Texas: American Association of Petroleum Geologists Bulletin, v. 29, p. 1733-1737.

Welder, F.A., and Reeves, R.D., 1962, Geology and groundwater resources of Uvalde County, Texas: Texas Water Commission Bulletin 6212, 263 p.

White, C.A., and Hill, R.T., 1887, On the Cretaceous formations of Texas and their relation to those of other portions of North America: Academy of Natural Sciences of Philadelphia Proceedings, p. 39-47.

Wilmarth, M.G., 1938, Lexicon of geologic names of the United States (including Alaska): U.S. Geological Survey Bulletin, 896, pts. 1-2, 2,396 p.

Wilson, Douglas, 1983, Paleoenvironments of the upper Cretaceous Anacacho Limestone in southwestern Texas: South Texas Geological Society Bulletin, v. 24, no. 2, p. 22-28.

Wilson, W.F., 1977, Relict tectonism in south Texas: South Texas Geological Society Bulletin, v. 17, no. 5, p. 23-25.

Zeiler, Michael, 1999, Modeling our world-The ESRI guide to geodatabase design: Redlands, Calif., Environmental Systems Research Institute Press, 10 p. 

Appendix 1-Wells Included in a Geodatabase of Geologic Framework, Structure, and Hydrogeologic Characteristics of the Knippa Gap Area in Eastern Uvalde and Western Medina Counties, Texas 

Appendix 1. Wells included in a geodatabase of geologic framework, structure, and hydrogeologic characteristics of the Knippa Gap Area in Eastern Uvalde and Western Medina Counties, Texas.

$[--$, not unavailable $]$

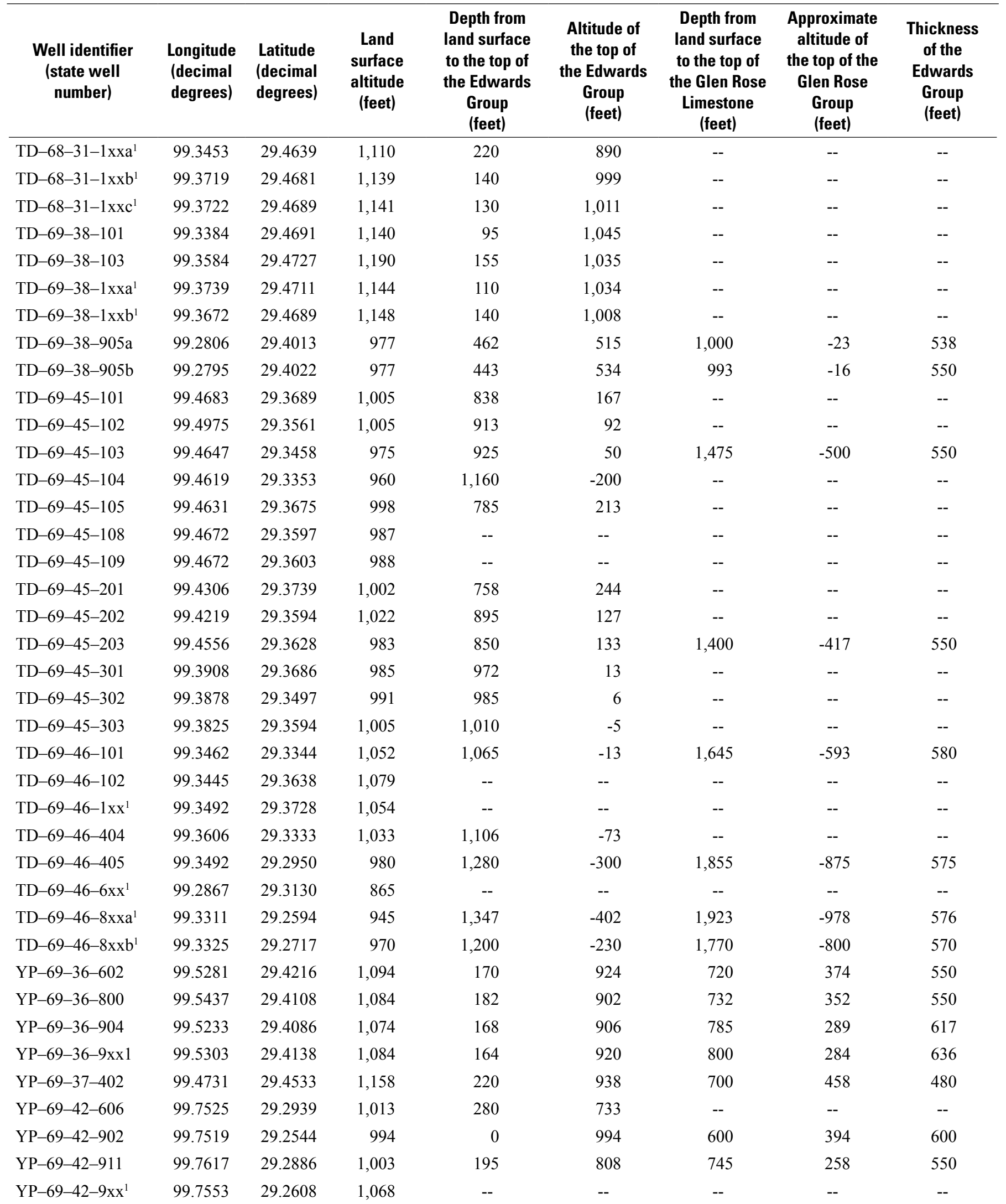


Appendix 1. Wells included in a geodatabase of geologic framework, structure, and hydrogeologic characteristics of the Knippa Gap Area in Eastern Uvalde and Western Medina Counties, Texas.-Continued

[--, not unavailable]

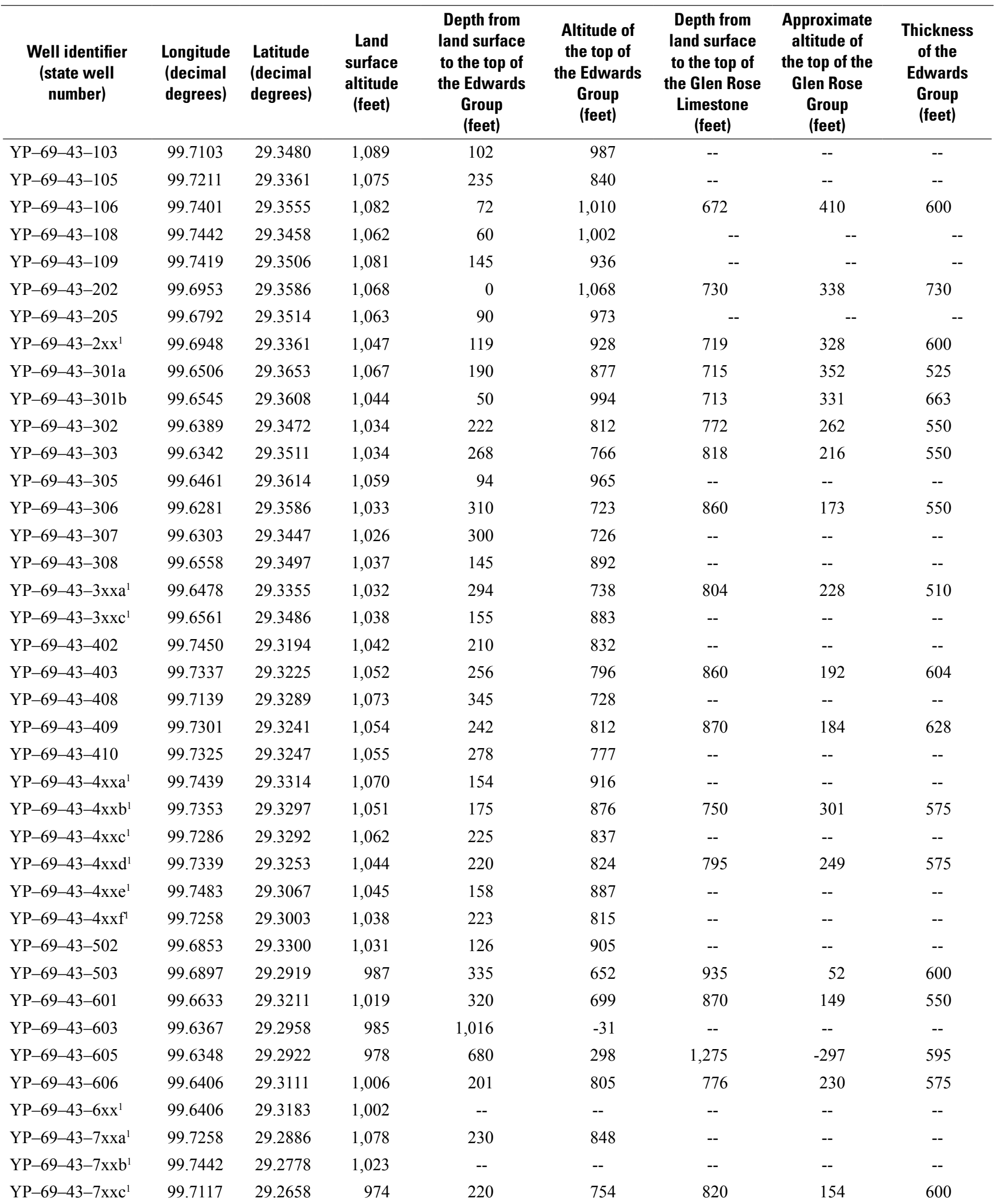


Appendix 1. Wells included in a geodatabase of geologic framework, structure, and hydrogeologic characteristics of the Knippa Gap Area in Eastern Uvalde and Western Medina Counties, Texas.-Continued

$[--$, not unavailable $]$

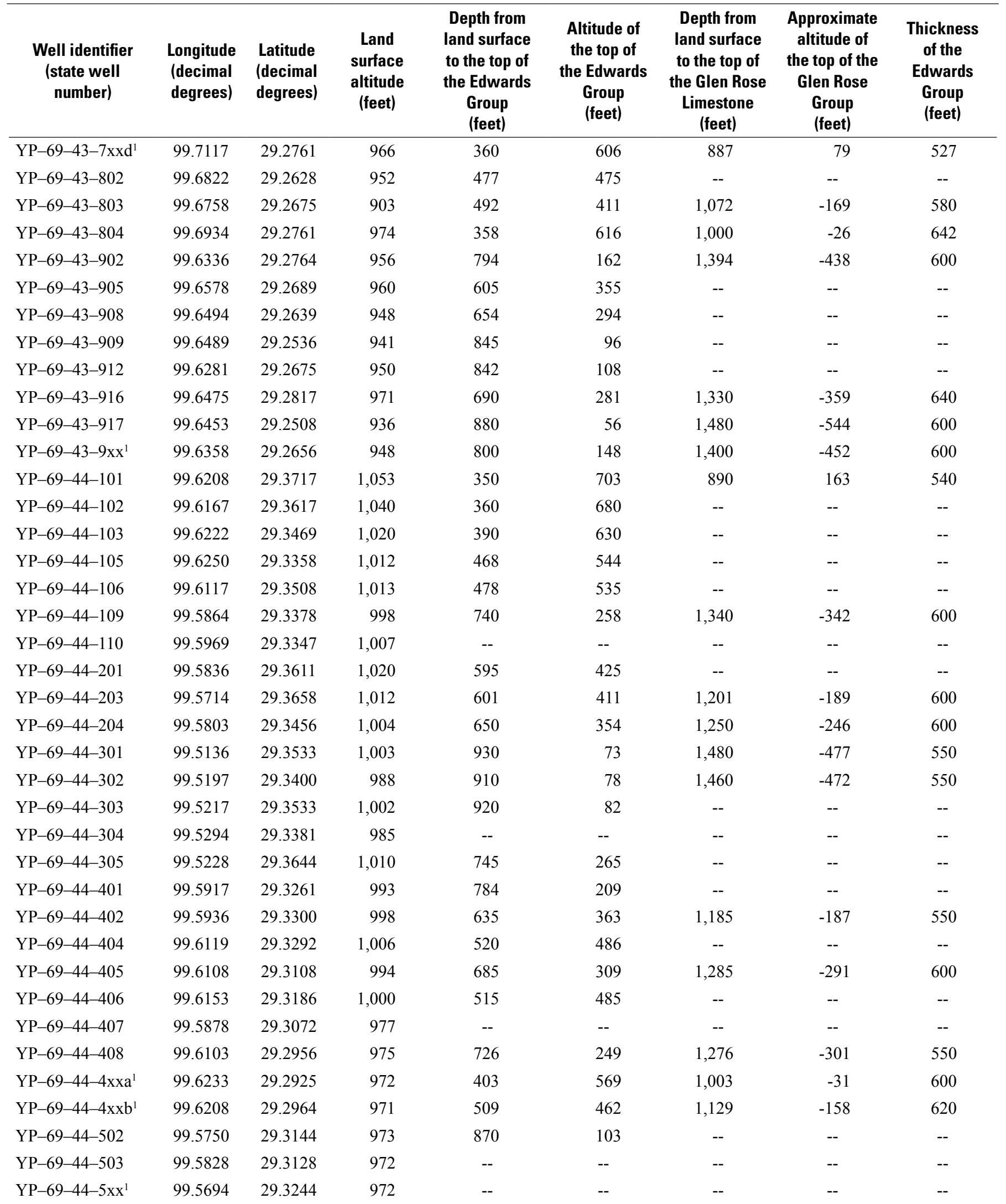


Appendix 1. Wells included in a geodatabase of geologic framework, structure, and hydrogeologic characteristics of the Knippa Gap Area in Eastern Uvalde and Western Medina Counties, Texas.-Continued

[--, not unavailable]

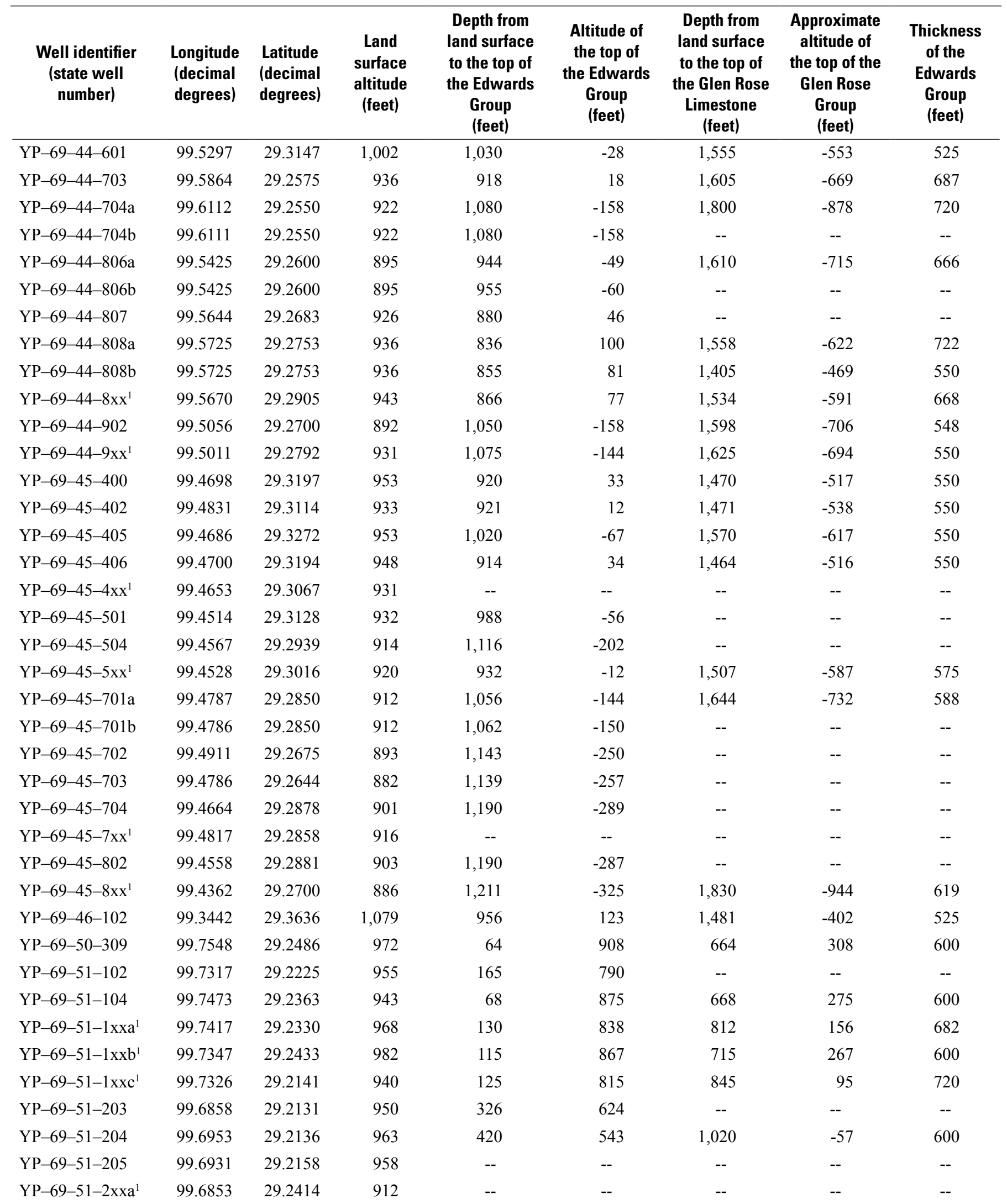


Appendix 1. Wells included in a geodatabase of geologic framework, structure, and hydrogeologic characteristics of the Knippa Gap Area in Eastern Uvalde and Western Medina Counties, Texas.-Continued

[--, not unavailable]

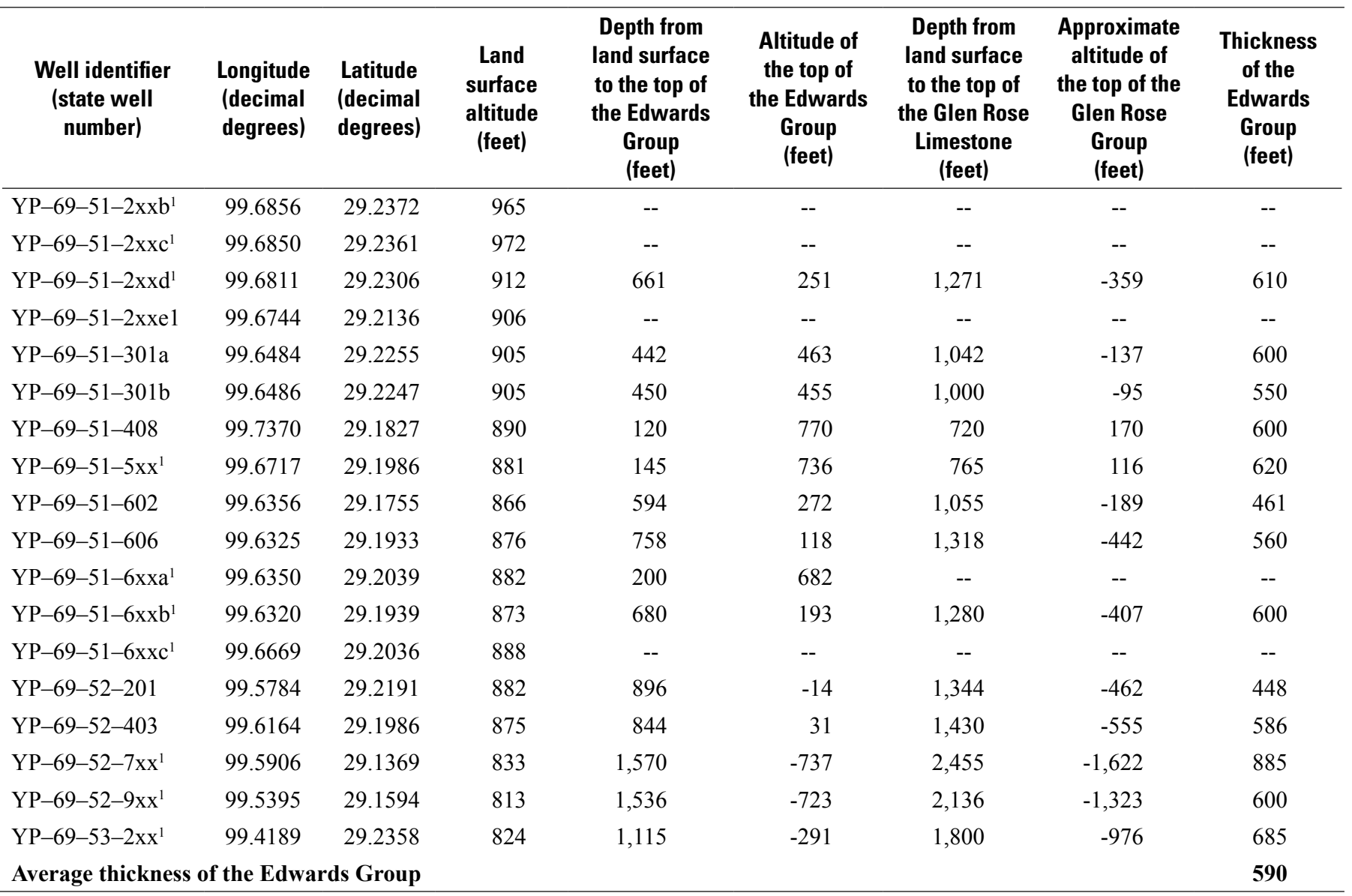

${ }^{1}$ Final State well number is pending assignment by the Texas Water Development Board.

Publishing support provided by Lafayette Publishing Service Center 



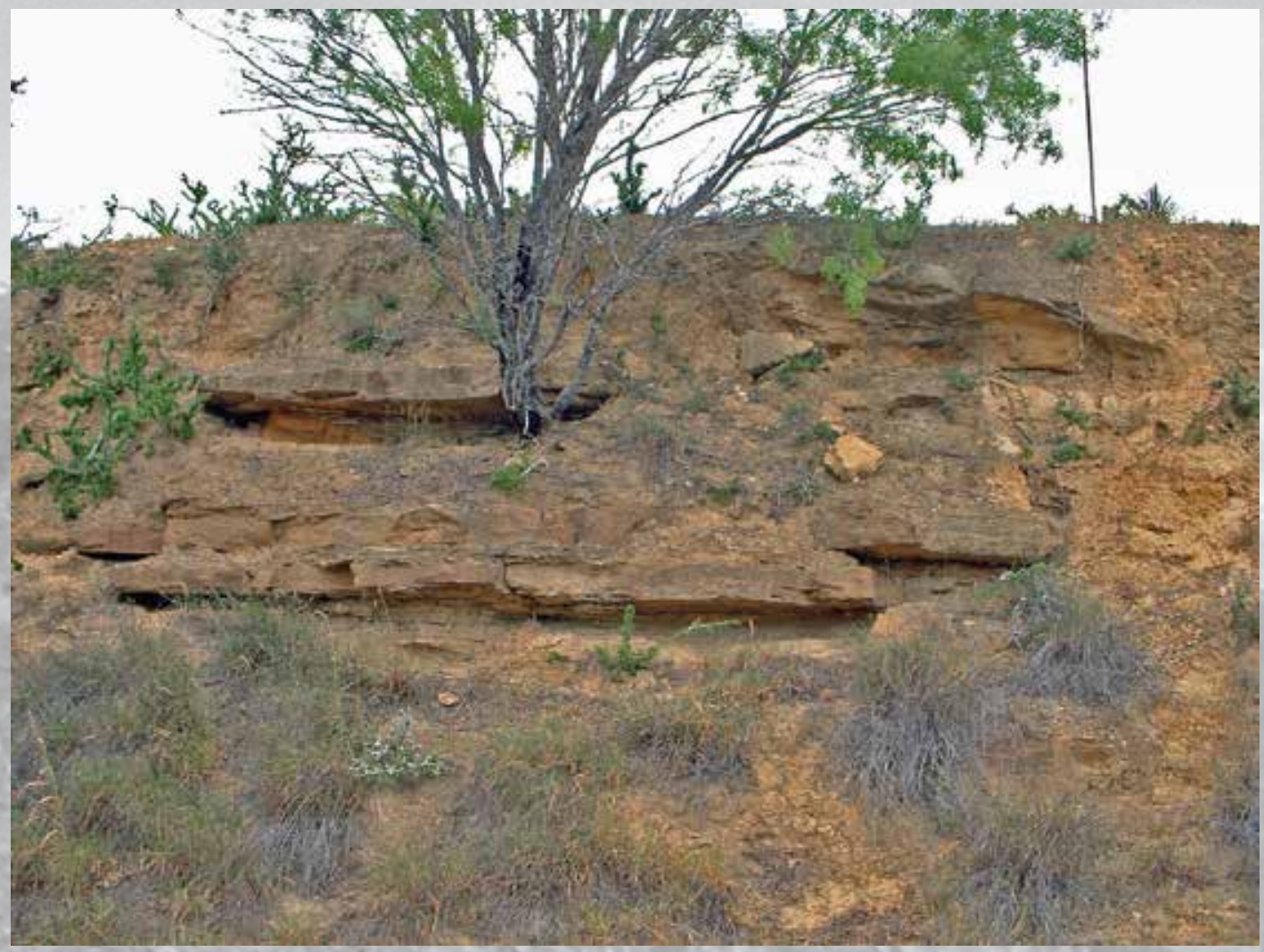

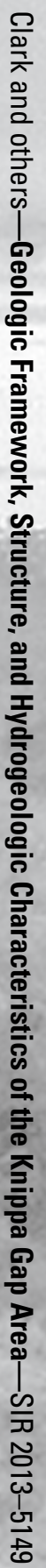
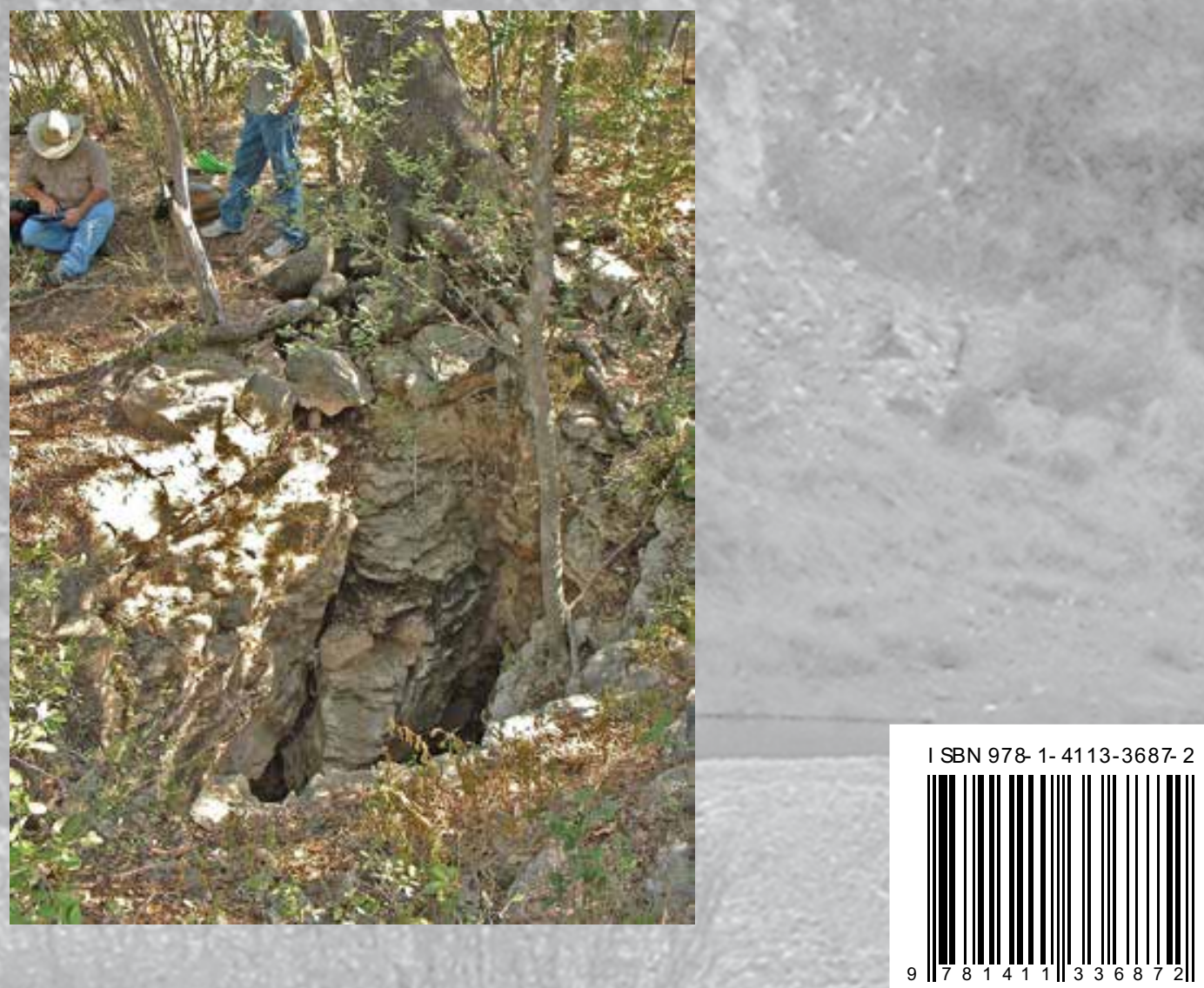